\title{
Was crustal contamination involved in the formation of the serpentine-free Udachnaya-East kimberlite? New insights into parental melts, liquidus assemblage and effects of alteration
}

\author{
Adam Abersteiner ${ }^{1 *}$, Vadim S. Kamenetsky ${ }^{1}$, Alexander V. Golovin ${ }^{2,3}$, \\ Maya Kamenetsky ${ }^{1}$ and Karsten Goemann ${ }^{4}$
}

${ }^{1}$ School of Physical Sciences, University of Tasmania, Hobart, Tasmania 7001, Australia.

${ }^{2}$ Sobolev Institute of Geology and Mineralogy, Siberian Branch Russian Academy of

Sciences, Koptyuga Pr. 3, Novosibirsk 630090, Russian Federation

${ }^{3}$ Diamond and Precious Metal Geology Institute, Siberian Branch Russian Academy of Sciences, Lenina Pr. 39, Yakutsk 677000, Russian Federation

${ }^{4}$ Central Science Laboratory, University of Tasmania, Hobart, Tasmania 7001, Australia.

*Corresponding author; e-mail: adam.abersteiner@utas.edu.au

ph: +61406717535

(c) The Author(s) 2018. Published by Oxford University Press. All rights reserved. For Permissions, please e-mail: journals.permissions@oup.com 


\section{ABSTRACT}

The petrologically unique Udachnaya-East kimberlite (Siberia, Russia) is characterised by unserpentinised and $\mathrm{H}_{2} \mathrm{O}$-poor volcaniclastic and coherent units that contain fresh olivine, along with abundant alkali-rich carbonates, chlorides, sulphides and sulphates in the groundmass. These mineralogical and geochemical characteristics have led to two divergent models that advocate different origins. It has been suggested that the unserpentinised units from Udachnaya-East are representative of pristine unaltered kimberlite. Conversely, the alkali-chlorine-sulphur enrichment has been attributed to interactions with crustal materials and, or, post-emplacement contamination by brines. The mineralogical and geochemical features and the compositions of melt inclusions in unserpentinised and serpentinised Udachnaya-East kimberlite varieties are compared in this study. Both varieties of kimberlite have similar major, compatible and incompatible trace element concentrations and primitive mantle normalised trace element patterns, groundmass textures and silicate, oxide and sulphide mineral compositions. However, these two kimberlite varieties are distinguished by: (i) the presence of unaltered olivine, abundant Na-K-Cl-S-rich minerals (i.e. chlorides, Sbearing alkali-carbonates, sodalite) and the absence of $\mathrm{H}_{2} \mathrm{O}$-rich phases (i.e. serpentine, iowaite $\left(\mathrm{Mg}_{4} \mathrm{Fe}^{3+}(\mathrm{OH})_{8} \mathrm{OCl} \cdot 3\left(\mathrm{H}_{2} \mathrm{O}\right)\right)$ in unserpentinised samples, and (ii) the absence of alkali- and chlorine-enriched phases in the groundmass and characteristic olivine alteration (i.e. replacement by serpentine and, or, iowaite) in serpentinised samples. In addition, melt inclusions hosted in olivine, monticellite, spinel and perovskite from unserpentinised and serpentinised kimberlite contain identical daughter phase assemblages that are dominated by alkali-carbonates, chlorides and sulphates/sulphides. This enrichment in alkalis, chlorine and sulphur in melt inclusions demonstrates that these elements were an intrinsic part of the parental magma. The paucity of alkali-carbonates and chlorides in the groundmass of serpentinised Udachnaya-East kimberlite is attributed to their instability and removal during 
post-emplacement alteration. All evidence previously used in support of crustal and brine contamination of the Udachnaya-East kimberlite is thoroughly evaluated. We demonstrate that "contamination models" are inconsistent with petrographic, geochemical and melt inclusion data. Our combined data suggest that the Udachnaya-East kimberlite crystallised from an essentially $\mathrm{H}_{2} \mathrm{O}$-poor, Si-Na-K-Cl-S-bearing carbonate-rich melt.

Key words: alkali-carbonates; chlorides; kimberlite; melt inclusions; Udachnaya-East. 


\section{INTRODUCTION}

Kimberlites are relatively rare and volumetrically insignificant rocks that originated from deeply-derived magmas from depths >150 km (e.g., Dawson, 1980; Clement et al., 1984; Mitchell, 1986; Pearson et al., 2014). Reconstructing the parental kimberlite melt composition is a fundamental task in understanding their petrogenesis, rheology, ascent and emplacement. Although whole-rock analyses of kimberlite rocks show that they are generally ultramafic, silica-poor and volatile $\left(\mathrm{H}_{2} \mathrm{O}, \mathrm{CO}_{2}\right)$-rich (e.g., Price et al., 2000; Le Roex et al., 2003; Becker \& Le Roex, 2006; Kjarsgaard et al., 2009), these compositions cannot be regarded as an accurate reflection of their parental melt. This classical conception of kimberlite melt compositions has been challenged in the past decade by a continually growing number of petrographic and melt inclusion studies (Golovin et al., 2003, 2007, 2017a, 2018; Kamenetsky et al., 2004, 2008, 2009a, 2013, 2014; Abersteiner et al., 2017a, 2017b, 2017c; Giuliani et al., 2017), and experimental work (Safonov et al., 2009, 2010; Sparks et al., 2009; Brooker et al., 2011; Russell et al., 2012; Kamenetsky \& Yaxley, 2015; Sharygin et al., 2015, 2017) which suggest a kimberlite melt which had initially carbonatitelike and silica-poor compositions.

The Udachnaya-East kimberlite (Siberia, Russia) is the flagship example for this new alternative model, largely due to the absence of serpentine, the preservation of fresh olivine and its atypical $\mathrm{H}_{2} \mathrm{O}$-poor and $\mathrm{Na}-\mathrm{K}-\mathrm{Cl}-\mathrm{S}$-enriched groundmass mineralogy (Egorov et al., 1986; Sharygin et al., 2003; Kamenetsky et al., 2004, 2008, 2012). This, combined with the study of melt inclusions in olivine, has led to the proposal that the Udachnaya-East kimberlite is "uniquely fresh" and that the kimberlites originated from essentially silica- $\mathrm{H}_{2} \mathrm{O}$-poor, alkali-Cl-enriched carbonatitic compositions (Kamenetsky et al., 2004, 2007b, 2009a, 2014; Golovin et al., 2007, 2017a). 
Analyses of the Udachnaya-East kimberlite have been complemented by additional studies of melt inclusions in olivine and primary inclusions in magmatic kimberlitic minerals (e.g., monticellite, Cr-spinel, perovskite, apatite) in other altered (i.e. serpentinised) kimberlites worldwide (e.g., Canada, Greenland, Finland, South Africa; Golovin et al., 2003, 2007, 2017a; Kamenetsky et al., 2009a, 2012, 2013; Mernagh et al., 2011; Abersteiner et al., 2017a, 2017b, 2017c; Giuliani et al., 2017). These studies have consistently produced similar results, advocating the Si-poor and alkali-Cl-S (and to a lesser extent P-F)-bearing carbonaterich nature of kimberlite melts entrapped within inclusions.

This alternative model for kimberlite petrogenesis has been heavily criticised in recent studies by Kopylova et al. (2013, 2016) and Kostrovitskiy et al. (2013). These authors emphasise that the unique Na-Cl-S-enriched groundmass mineralogy of the Udachnaya-East pipe is not exceptional or representative of pristine kimberlite, but can be explained by:(i) contamination of the kimberlite magma by crustal material, and (ii) interaction with external $\mathrm{Na}-\mathrm{Ca}-\mathrm{Cl}$ brines that precipitate salts and carbonates.

Our study provides new constraints on the origin of the unusual groundmass mineralogy and composition of the Udachnaya-East kimberlite and the evolution of its parental melt. We present detailed petrographic studies along with geochemical and melt inclusion analyses from a variety of serpentinised and unserpentinised volcaniclastic and coherent kimberlite samples. This comparison aims to evaluate comprehensively whether the $\mathrm{Na}-\mathrm{Cl}$-S-enrichment in the Udachnaya-East was inherited from a magmatic (i.e. mantlederived melt) or secondary (i.e. crustal) source.

\section{GENERAL GEOLOGY}


The Devonian ( 365 - 367 Ma; Kinny et al., 1997; Kamenetsky et al., 2009b) Udachnaya kimberlite is part of the Daldyn-Alakit kimberlite field in the Siberian craton (Russia; Fig. 1). The Udachnaya kimberlite intruded thick $(>2 \mathrm{~km})$ Ordovician and Devonian limestones, dolomites, marls, siltstones and mudstones (Marshintsev, 1986; Kharkiv et al., 1991, 1998; Zinchuk et al., 1993). This kimberlite forms a composite twin-diatreme structure (i.e. an older eastern and younger western body) that diverges at $\sim 250 \mathrm{~m}$ depth (Fig. 2; Kharkiv et al., 1991; Zinchuk et al., 1993). The complex nature of the Udachnaya kimberlite suggests that it formed from multiple magmatic events. The eastern and western Udachnaya kimberlite bodies are different in terms of mineralogy, petrography, composition and degree of alteration. The western body exhibits extensive alteration (i.e. serpentinisation) typical of kimberlites worldwide.

\section{Megascopic and macroscopic study of Udachnaya-East kimberlite units}

In this study we use the term kimberlite 'units' instead of 'phases' (see Kopylova et al., 2016). This is because a separate 'phase' of kimberlite magmatism requires:(i) different timing of formation; (ii) a clear boundary between the first and secondary kimberlite varieties. Scott Smith et al. (2013) noted in their kimberlite classification scheme that: "One phase of kimberlite may comprise one or more lithological units, lithofacies, facies and, or, facies associations, thus the terms are not synonymous". The dating of individual kimberlite units from the Udachnaya pipe has never been conducted, even where the boundaries between the different units are clearly defined. In this study, we examined samples from kimberlite units 9 and 10 from the eastern body (Fig. 2). According to the classification scheme of Scott Smith et al. (2013), unit 9 is volcaniclastic kimberlite (VK), where fragmentation of magma occurred, whereas unit 10 is classed as coherent kimberlite (CK), 
where the magma did not undergo fragmentation. The classification of unit 9 depends on the individual hand sample studied; it can be classified as either olivine-rich pyroclastic kimberlite (PK; Supplementary Data Electronic Appendix 2: Fig. S1) or magmaclast-rich PK (Electronic Appendix 2: Fig. S2), as gravitational separation of minerals in the melt during emplacement of unit 9 has been noted (Kamenetsky et al., 2012).

Xenolith-poor $(>5-15 \%)$ VK unit 9 is located in the central part of the UdachnayaEast pipe and is surrounded by xenolith-rich (> $15-50 \%$ ) VK unit 8 (Fig. 2; Supplementary Data Electronic Appendix 2: Figs. S3 and S4). Sometimes there are clear boundaries between kimberlite unit 9 and the very xenolith-rich (> $50-75 \%$; Electronic Appendix 2: Fig. S5) unit 7 VK. Units 8 and 9 also contain dykes and veins (ranging in size from several $\mathrm{cm}$ to several meters) of xenolith-poor ( $>0-5 \%$; Fig. 3a; Electronic Appendix 2; Fig. S6) CK (unit 10 in Fig. 2). Units 7 and 8 are partially serpentinised across the entire $370-640 \mathrm{~m}$ depth interval. Kimberlite units 9 and 10 can be separated across depth intervals $370-410,410-$ 500 and $500-640 \mathrm{~m}$. Although the textural and structural characteristics of units 9 and 10 are identical, there are various changes in groundmass mineralogy that take place at different depths (Fig. 2).

The so-called "salty" xenolith-poor unserpentinised VK (Unit 9a in Figs 2 and 3; Supplementary Data Electronic Appendix 2: Figs. S4b, S7, S8a, S9, S11b and S12b) is located between $410-500 \mathrm{~m}( \pm 10 \mathrm{~m})$ depth. This kimberlite is characterised by the following features:

(i) The absence of serpentine and very low $\mathrm{H}_{2} \mathrm{O}(<0.6 \mathrm{wt} \%)$ content (Kamenetsky et al., 2008, 2012).

(ii) The presence of alkali-rich carbonates, chlorides, sulphates and sulphides in the groundmass (Table 1), which is reflected by enrichment in alkalis $\left(\mathrm{Na}_{2} \mathrm{O}\right.$ up to $6.2 \mathrm{wt} \%$ and 
$\mathrm{K}_{2} \mathrm{O}$ up to $2.2 \mathrm{wt} \%$ ), chlorine (up to $6.1 \mathrm{wt} \%$ ) and sulphur (up to $0.5 \mathrm{wt} \%$; Table 2;

Supplementary Data Electronic Appendix 2: Figs. S7b, S9b, S11c and S12b; Sharygin et al., 2004; 2007; Kamenetsky et al., 2004, 2007a, 2012, 2014; d'Eyrames et al., 2017; Golovin et al., 2017b; Kitayama et al., 2017).

(iii) The presence of chloride and chloride-carbonate (as well as alkali carbonates) "nodules", which reach up to $30 \mathrm{~cm}$ in size (Supplementary Data Electronic Appendix 2: Figs. S8 - S10; Kamenetsky et al., 2007b).

(iv) The absence of cracks, caverns and cavities (Supplementary Data Electronic Appendix 2: Figs. S7 and S8a) that contain secondary hydrothermal assemblages, which are common in other units of the Udachnaya-East pipe (Mikhailenko et al., in press).

(v) The excellent preservation of mantle-derived lherzolite, dunite, harzburgite, eclogite and pyroxenite xenoliths (e.g., Agashev et al., 2012; Doucet et al., 2012, 2013; Ionov et al., 2017; Supplementary Data Electronic Appendix 2: Figs. S11 and S12).

It should be noted that chloride and chloride-carbonate "nodules" occupy between 3 5 vol. \% of the VK kimberlite unit (Supplementary Data Electronic Appendix 2: Fig. S8a) and the sedimentary xenolith content is $\leq 6$ vol. \% (Kamenetsky et al., 2014). When this "salty" kimberlite is exposed to the atmosphere, it is rapidly degraded due to the dissolution and decomposition of chlorides, alkali-carbonates and alkali-sulphates (Supplementary Data Electronic Appendix 2: Fig. S13). This same kimberlite was classified by Kopylova et al. (2016) into two so-called "phases": olivine-rich pyroclastic kimberlite (PK) and magmaclastrich PK.

Dykes and veins of xenolith-poor unserpentinised CK (unit 10 inside unit 9a in Fig. 2) are present within unserpentinised VK unit 9a at the same $410-500 \mathrm{~m}$ level. These CK 
dykes and veins share the same characteristic features (i, ii and iv) as VK unit 9a, except that the chloride and chloride-carbonate "nodules" (iii) are absent. The high $\mathrm{Na}_{2} \mathrm{O}(3.4 \mathrm{wt} \%)$ and $\mathrm{Cl}$ (0.9 wt \%; Sharygin et al., 2015) contents led to the formation of Na-Ca-carbonates, chlorides and alkali-sulphates in the CK units (e.g., Fig. 5 from Kitayama et al., 2017).

In general, all units of kimberlite at the $410-500 \mathrm{~m}$ depth interval have been referred to as 'Serpentine Free Udachnaya-East' (SFUE) kimberlite by Kopylova et al. (2013) and Kostrovitskiy et al. (2013). Note that kimberlitic units 9 and 10 are partially serpentinised at depths of $370-410$ and $500-640 \mathrm{~m}$ (Fig. 2; unit $9 \mathrm{~b}$ and 10). The chloride, alkali-carbonate and alkali-sulphate assemblages in the groundmass of these units are absent, along with chloride and chloride-carbonate "nodules" in unit 9b. In addition, voids, caverns and cracks appear, in which hydrothermal mineral assemblages are present, which include calcite, gypsum, halite, and iowaite (Supplementary Data Electronic Appendix 2: Figs. S14 and S15; Mikhailenko et al., in press).

\section{ANALYTICAL METHODS}

Eleven specimens of the Udachnaya-East (K16/05, K20-05, K28/05, K17/04, K25/04, K-U, UV-K1-15, K2-03, K24/04A, K24/04B, UV-K1-05) kimberlite were examined (Table 1). These samples were also analysed by Kamenetsky et al. (2012; see Supplementary Data Electronic Appendix 1 for methodology and complete data set) and prepared as epoxy resin rock and grain mounts polished using kerosene as lubricant to avoid dissolution of any watersoluble minerals. Phases such as alkali-carbonates and chlorides are very susceptible to dissolution and re-precipitation due to hydrous interaction (e.g., water contact and atmospheric moisture). Initial optical petrographic and mineralogical investigations of 
samples were performed on a Nikon Eclipse 50i POL microscope at the University of Tasmania.

Detailed examination of groundmass phases and inclusions in minerals were performed using a Hitachi SU-70 field emission (FE) scanning electron microscope (SEM) equipped with an Oxford AZtec Energy XMax 80 detector at the Central Science Laboratory, University of Tasmania. A beam accelerating voltage of $15 \mathrm{kV}$ was used to produce highresolution backscattered electron (BSE) images of minerals and energy-dispersive X-ray spectroscopy (EDS) semi-quantitative analyses and elemental maps of minerals and inclusions.

\section{PETROGRAPHY}

Samples of the Udachnaya-East (UE) kimberlite were selected based on the presence of serpentine as a replacement mineral after olivine and as an interstitial groundmass phase. Six partially serpentinised samples (K16/05, K20-05, K28/05, K17/04, K25/04, K-U) were derived from depth intervals of $480-520 \mathrm{~m}$ (below the SFUE) and $400-420 \mathrm{~m}$ (roof of the SFUE) and five unserpentinised samples (UV-K1-15, K2-03, K24/04A, K24/04B, UV-K105) were sourced from a depth interval of $440-500 \mathrm{~m}$ (within the SFUE; Table 1). The petrography of both serpentinised and unserpentinised varieties of the UE kimberlites have been extensively described in the literature (e.g., Marshintsev, 1986; Egorov et al.,1991; Kharkiv et al., 1991; Kamenetsky et al., 2004, 2008, 2012, 2014; Kopylova et al., 2013, 2016; Kostrovitskiy et al., 2013; d'Eyrames et al., 2017; Kitayama et al., 2017).

The UE samples were analysed by optical microscopy and FE-SEM. Samples UVK1-15, K2-03, K24/04B, UV-K1-05 (unit 9a in Fig. 2, "salty" unserpentinised kimberlite; see 
also Fig. 3 and Supplementary Data Electronic Appendix 2: Figs. S4b, S7, S8a, S9, S11 and S12) and K20-05, K17/04, K25/04, K-U (unit 9b in Fig. 2, partially serpentinised kimberlite; Electronic Appendix 2: Figs S3, S5b, S14 and S15) are texturally defined as massive VK. Samples K16/05 and K28/05 (Electronic Appendix 2: Fig. S16) are autolithic clasts (AC) of kimberlite (or autoliths) hosted in unit 9b VK. These samples are composed of kimberlite material surrounding a fragment of sedimentary rock in the core. Sample K24/04A is representative of an unserpentinised CK dyke or vein in unit 9a (Figs 2 and 3).

Unserpentinised CK occurs as thin $(5-10 \mathrm{~cm})$ dykes that intrude unserpentinised VK. These are dark in colour (grey-black) and generally uniform in grain size, xenolith-poor and contain abundant fine-grained olivine (Figs $3 \mathrm{a}-\mathrm{c}$, e and f) that are preferentially aligned, and higher abundances (up to 15 vol.\%) of oxides (e.g., spinel, perovskite) than in VK. VK is generally light-grey in colour, has a macrocrystic texture (Figs. 3a-e) and contains a higher abundance of randomly orientated olivine and carbonate in the groundmass, as well as minor amounts of mantle-derived (e.g., ilmenite, clinopyroxene, garnet, and phlogopite) and crustal xenocrysts (e.g., amphibole, alkali-feldspar) and xenoliths.

Olivine is the dominant mineral (40 - 60 vol.\%) in CK and VK from both unserpentinised and serpentinised varieties and is petrographically and geochemically similar, represented by two morphologically distinct populations which were described in detail by Kamenetsky et al. (2008). The first type of olivine (olivine-I) is round to ovoid in shape or occurs as angular fragments up to several millimetres in size. Large olivine grains $(>0.5 \mathrm{~mm})$ are less common in CK than in VK. The second type of olivine (olivine-II) forms smaller $(<250 \mu \mathrm{m})$ euhedral grains that commonly exhibit complex zoning patterns (Figs. 3, 4, 6 and 7; Supplementary Data Electronic Appendix 2: Fig. S17), reflecting variation in Fo-content and a complex crystallisation history (Kamenetsky et al., 2008). The cores of both olivine 
types exhibit variable Fo contents $(0.85-0.94$ mol.\%) but most compositions are clustered between Fo $0.91-0.94$ mol.\% (Fig. 5).

Both unserpentinised and serpentinised varieties of $\mathrm{CK}$ and $\mathrm{VK}$ are represented by broadly similar silicate (olivine, monticellite, phlogopite), carbonate (calcite), oxide (perovskite, macrocrystic ilmenite, Fe-Ti-Mg-Al-Cr-spinel (Mg-Ti-magnetite, magnesian ulvöspinel-magnetite (MUM), pleonaste, Cr-spinel), phosphate (apatite) and sulphide (Fe-Nisulphides, djerfisherite $\left.\left(\mathrm{K}_{6} \mathrm{Na}\left(\mathrm{Fe}^{2+}, \mathrm{Cu}, \mathrm{Ni}\right){ }_{25} \mathrm{~S}_{26} \mathrm{Cl}\right)\right)$ groundmass assemblages. A summary of the depth constraints, mineralogical similarities and differences, as well as their approximate abundances in the studied samples is presented in Table 1.

In both unserpentinised and serpentinised CK and VK kimberlite varieties, monticellite is a common groundmass phase that typically occurs as discrete subhedral to euhedral $(10-70 \mu \mathrm{m})$ grains (Fig. 4b and Supplementary Data Electronic Appendix 2, Fig. $\mathrm{S} 17 \mathrm{a})$. In rare cases, monticellite is a replacement mineral after olivine in unserpentinised kimberlite (Electronic Appendix 2, Fig. S17a; Abersteiner et al. (2017b)). The distribution of monticellite is extremely heterogeneous on a millimetre scale; it may be abundant in some areas, but absent in others. Phlogopite usually occurs as clusters of microphenocrysts $(<15$ $\mu \mathrm{m}$ ), but may also occur as larger (up to $1 \mathrm{~mm}$ ) rare macrocrysts. Calcite is a ubiquitous phase that is interstitial to most other phases (Figs. 4c and d; Supplementary Data Electronic Appendix 2, Figs. S17a and c). Only in unserpentinised samples does calcite also form euhedral needle-like grains (Electronic Appendix 2, Fig. S17b). Euhedral perovskite and spinel range in size from $10-100 \mu \mathrm{m}$ and are more common in CK (Fig. 3f) than in VK (Fig. 3d). Cr-spinel and Mg-Ti-magnetite usually form well-developed atoll shapes (see definition by Mitchell (1986) and Roeder \& Schulze (2008)). Here, the euhedral zoned core is surrounded by an intermediate 'lagoon' ( $5-15 \mu \mathrm{m}$ thick) zone composed of pleonaste and an outer thin rim $(1-5 \mu \mathrm{m})$ of $(\mathrm{Mg}-)$ magnetite which parallels the shape of the core exactly 
(Electronic Appendix 2, Fig. S17c). These atoll-shapes show excellent preservation in unserpentinised samples. Apatite is a rare groundmass phase that occurs as acicular microphenocrysts that are $1-10 \mu \mathrm{m}$ in size. Sulphides are minor groundmass phases that are generally amorphous and interstitial to most other groundmass phases (i.e. silicates, oxides) and range in size from $5-100 \mu \mathrm{m}$ (Supplementary Data Electronic Appendix 2, Fig. S17d).

The unserpentinised UE kimberlite samples are mineralogically and geochemically distinguished from serpentinised samples by: (i) the absence of $\mathrm{H}_{2} \mathrm{O}$-rich phases in the groundmass (i.e. serpentine and iowaite $\left(\mathrm{Mg}_{4} \mathrm{Fe}^{3+}(\mathrm{OH})_{8} \mathrm{OCl} \cdot 3\left(\mathrm{H}_{2} \mathrm{O}\right)\right)$; (ii) The excellent preservation of euhedral olivine which has near-perfect crystal faces (Figs 4a, b and 6); (iii) The presence of groundmass halite and sylvite, which are usually interstitial to other groundmass phases (e.g., silicates, oxides, phosphates etc). In addition, there are larger irregular to semi angular shaped halite "nodules", which are up to several centimetres across (Kamenetsky et al., 2007). These halite nodules commonly contain bleb-like inclusions (1 $60 \mu \mathrm{m}$ in size) of sylvite (Supplementary Data Electronic Appendix 2, Fig. S18) as well as lesser amounts of calcite and, or, phlogopite. (iv) The presence of abundant (up to 15 vol.\%) alkali (Na, K) carbonates (e.g., shortite $\left(\mathrm{Na}_{2} \mathrm{Ca}_{2}\left(\mathrm{CO}_{3}\right)_{3}\right)$, including some S-enriched (i.e. sulphate) varieties (up to $2-4.7 \mathrm{wt} \% \mathrm{~S}$ )) and sodalite $\left(\mathrm{Na}_{8} \mathrm{Al}_{6} \mathrm{Si}_{6} \mathrm{O}_{24} \mathrm{Cl}_{2}\right)$. In contrast, serpentinised UE samples contain varying amounts of serpentine and iowaite $(\sim 10-30 \%)$, which replaces olivine grains along rims and fractures (Figs 4c, d, 7 and Supplementary Data Electronic Appendix 2, Figs. S19 and S4). Olivine replacement is sometimes accompanied by zoning from serpentine along the olivine contact towards iowaite along the peripheries (Electronic Appendix 2, Fig. S19). Iowaite also occasionally forms large (up to $250 \mu \mathrm{m}$ ) aggregates in the groundmass. Areas directly in contact or within a few millimetres of groundmass surrounding crustal xenoliths or xenocrysts are characterised by more intense serpentinisation (Electronic Appendix 2, Fig. S20). In serpentinised samples, xenocrysts of 
ilmenite and garnet also exhibit variably thick $(25->100 \mu \mathrm{m})$ reaction rims, in which ilmenite is partially replaced by Ti-Fe-Mg-spinel and perovskite, and pyrope-almandine garnet is partially replaced by phlogopite. Although garnet xenocrysts were not observed in unserpentinised samples, ilmenite shows a stronger degree of preservation along rims where grains are surrounded by only thin $(<5-10 \mu \mathrm{m})$ reaction rims of Ti-Fe-oxides.

\section{GEOCHEMISTRY}

The major element compositions of serpentinised and unserpentinised $\mathrm{CK}$ and $\mathrm{VK}$ are characterised by low-silica $\left(26.6-32 \mathrm{wt} \% \mathrm{SiO}_{2}\right), \mathrm{FeO}_{\text {total }}(7.5-8.8 \mathrm{wt} \%)$ and $\mathrm{Al}_{2} \mathrm{O}_{3}(1.3-$ 2.1 wt \%), and moderate-to-high $\mathrm{CaO}\left(9.5-14\right.$ wt \%) and $\mathrm{CO}_{2}(6.3-10.5$ wt \%; Figs. 8a -

c; Table 2). These compositions are consistent with whole-rock analyses of other kimberlites from Yakutia (Vasilenko et al., 2002) and worldwide (O'Brien \& Tyni, 1999; Price et al., 2000; le Roex et al., 2003; Becker \& le Roex, 2006; Nowicki et al., 2008; Kjarsgaard et al., 2009; Tappe et al., 2011, 2013, 2016). Unserpentinised samples are distinct from partially serpentinised samples as they are enriched in alkalis $\left(\mathrm{K}_{2} \mathrm{O}-\right.$ up to $2.23 \mathrm{wt} \%$, and $\mathrm{Na}_{2} \mathrm{O}-$ up to $6.10 \mathrm{wt} \%$ ), chlorine (up to $6.11 \mathrm{wt} \%$ ) and sulphur (up to $0.5 \mathrm{wt} \%$; Figs $8 \mathrm{~d}-\mathrm{h}$; Table 2; Kamenetsky et al., 2004, 2012; Kitayama et al., 2017). The absence or paucity of serpentine/iowaite in kimberlite samples is reflected by the extremely low $\mathrm{H}_{2} \mathrm{O}$-contents $(\leq 0.6 \mathrm{wt} \%$; average from 11 samples $=0.35 \mathrm{wt} \%$; Supplementary Data Electronic Appendix 1). In contrast, partially serpentinised varieties of the UE kimberlite, along with the overwhelming majority of other localities worldwide, have extremely low $\mathrm{Na}_{2} \mathrm{O}$ (typically $<0.5 \mathrm{wt} \%$ ) and $\mathrm{Cl}$ (typically $<0.1 \mathrm{wt} \%$, rarely higher than $1 \mathrm{wt} \%$; Nowicki et al., 2008) and highly variable $\mathrm{H}_{2} \mathrm{O}(\geq 0.6$ - >16 wt \%; Fig. 8d - h; Shee, 1985; Mitchell, 1986; O'Brien \& Tyni, 1999; Price et al., 2000; Vasilenko et al., 2002; le Roex et al., 2003; Becker \& le Roex, 
2006; Kjarsgaard et al., 2009; Tappe et al., 2016). Overall, the $\mathrm{Na}_{2} \mathrm{O}, \mathrm{Cl}$ and to a lesser extent $\mathrm{K}_{2} \mathrm{O}$ and $\mathrm{S}$ contents in each UE sample are directly related to the $\mathrm{H}_{2} \mathrm{O}$ contents of each sample (i.e. degree of serpentinisation - average $\mathrm{H}_{2} \mathrm{O}$-content $=2.5 \mathrm{wt} \%$ from 18 samples; Supplementary Data Electronic Appendix 1). Samples with $\leq 0.6 \mathrm{wt} \% \mathrm{H}_{2} \mathrm{O}$ (i.e. unserpentinised) exhibit the greatest variability in alkali, chlorine and sulphur contents, whereas samples with $0.6-4.5$ wt $\% \mathrm{H}_{2} \mathrm{O}$ (i.e. serpentinised; Supplementary Data Electronic Appendix 1) are generally significantly depleted in these elements (Figs 8d and e; Table 2).

Primitive-mantle normalised (after Sun \& McDonough, 1989) trace element diagrams show typical kimberlite enrichment in most incompatible elements and depletions in heavy rare-earth elements (HREE) and Y (Fig. 9). This is accompanied by strong negative anomalies in $\mathrm{K}, \mathrm{Pb}, \mathrm{P}$, $\mathrm{Ti}$ and to a lesser extent in $\mathrm{Ba}, \mathrm{Sr}, \mathrm{Zr}$ and $\mathrm{Hf}$ relative to elements of similar incompatibility. Both serpentinised and unserpentinised CK and VK samples have almost identical trace elements patterns and concentrations.

\section{INCLUSIONS IN MINERALS}

Analyses of melt inclusions hosted by kimberlitic minerals provide 'snapshots' of the kimberlite melt composition prior to or during solidification of the magma and are unaffected by post-magmatic modifications of the rock. In our study, olivine-hosted melt inclusions occur along healed fractures and planes, and are therefore assigned a secondary origin (as defined by Roedder, 1984). Although the majority of these inclusions are isolated within the host-olivine, many are interconnected by thin channels, and therefore modification of the original melt composition by 'necking down' is possible. 
Inclusions were examined in olivine, monticellite, spinel (Cr-spinel/MUM) and perovskite in the groundmass as well as in grain separates from both unserpentinised and serpentinised samples. The compositions of inclusions were analysed by FE-SEM. Representative bulk compositions of melt inclusions cannot be accurately quantified because of: i) the potential for the loss of water-soluble phases during exposure of the inclusions during sample preparation and storage (Supplementary Data Electronic Appendix 2, Fig. S21); ii) melt inclusions in kimberlitic minerals are heterogeneous in composition; iii) analyses of exposed melt inclusions only provide a two-dimensional cross section. Therefore, qualitative reconstructions of melt inclusion compositions are based on a statistically high number of analyses.

In this study, over 150 inclusions in olivine were analysed. In addition, over 3000 inclusions have been analysed in numerous studies of olivine from the Udachnaya-East kimberlite (Golovin et al., 2003, 2007, 2017a; Kamenetsky et al., 2004, 2008, 2009a, 2012; Mernagh et al., 2011). The majority of secondary inclusions in olivine in this study are typically round to amoeboid in shape and less than $5 \mu \mathrm{m}$ in size (Figs. 10, 11a and b). However, larger irregular-shaped inclusions may reach up to $50-150 \mu \mathrm{m}$ or more in size (Figs. 11c, d, 12 and 13). The daughter phase assemblages in olivine-hosted inclusions from both unserpentinised and serpentinised samples are virtually identical; they contain complex daughter phase assemblages of (in order of relative abundance): halite/sylvite, $\mathrm{Ca}-\mathrm{Mg}-$ bearing alkali $(\mathrm{Na}, \mathrm{K}, \mathrm{Ba}, \mathrm{Sr})$ carbonates (e.g., commonly shortite $\left(\mathrm{Na}_{2} \mathrm{Ca}_{2}\left(\mathrm{CO}_{3}\right)_{3}\right)$ as well as nyerereite $\left(\mathrm{Na}_{2} \mathrm{Ca}\left(\mathrm{CO}_{3}\right)_{2}\right)$, dolomite, calcite, natrite $\left(\mathrm{Na}_{2} \mathrm{CO}_{3}\right)$, strontianite $\left(\mathrm{SrCO}_{3}\right.$ and some S-bearing varieties), Fe-Ti-Mg-Cr-Al-spinels, alkali (Na, K)-rich sulphates (e.g., arcanite $\left.\left(\mathrm{K}_{2} \mathrm{SO}_{4}\right)\right)$, tetraferriphlogopite $\left(\mathrm{KMg}_{3} \mathrm{Fe}^{3+} \mathrm{Si}_{3} \mathrm{O}_{10}(\mathrm{OH})_{2}\right)$, djerfisherite, Fe-Ni-sulphides, phlogopite, monticellite, perovskite, humite $\left((\mathrm{Mg}, \mathrm{Fe})_{7}\left(\mathrm{SiO}_{4}\right)_{3}(\mathrm{~F}, \mathrm{OH})_{2}\right)$ and apatite (Table 3; Figs. $11-13)$. Olivine also hosts numerous euhedral inclusions $(<20 \mu \mathrm{m})$ of spinel (MUM, 
Cr-spinel, magnetite), needle-shaped rutile, and perovskite, as well as rare rounded (up to 50 $\mu \mathrm{m})$ inclusions of orthopyroxene and clinopyroxene within olivine cores.

Monticellite (Figs. 14a - c), spinel (Figs. 14d-f) and perovskite (Fig. 14g) host numerous multiphase primary inclusions $(\mathrm{n}=>30)$ that are typically $<10 \mu \mathrm{m}$ in size and irregular in shape. Melt inclusions in groundmass minerals are less common than in olivine, largely due to the smaller sizes of the host grain and relative abundance. Phase assemblages hosted in these inclusions are analogous to multiphase inclusions in olivine, and are dominated by: sylvite/halite, Ca-Mg-bearing alkali (Na, K)-carbonates, Fe-Mg-Ti-spinel, alkali (Na, K)-sulphates, phlogopite and perovskite (Table 3). In addition, spinel hosts numerous larger (up to $20 \mu \mathrm{m}$ ) rounded monocrystalline olivine inclusions.

Interstitial groundmass calcite hosts abundant rounded multiphase inclusions $(\mathrm{n}=$ $>20$ ) ranging in size from $1-50 \mu \mathrm{m}$ in size. These inclusions are comprised of (in order of relative abundance) halite/sylvite, $\mathrm{Ca}-\mathrm{Mg}$-bearing alkali $(\mathrm{Na}, \mathrm{K} \pm \mathrm{S})$ carbonates and djerfisherite (Table 3; Fig. 14h).

\section{DISCUSSION}

\section{Kimberlites: Rock vs Melt Compositions}

Reconstructing the composition of kimberlites is challenging as kimberlite whole-rocks can no longer be considered as representative of their parental melts. This is because parental kimberlite melts are inevitably altered en route to the surface and upon emplacement. This includes: i) reactions between the kimberlite magma and entrained mantle and crustal material (Hunter \& Taylor, 1982; Smith et al., 2004; Buse et al., 2010; Kamenetsky \& Yaxley, 2015; Soltys et al., 2016; Tappe et al., 2016; Sharygin et al., 2017; Stone \& Luth, 
2017). Furthermore, entrained xenogenic material such as mantle-derived olivine

(Kamenetsky et al., 2008; Brett et al., 2009; Arndt et al., 2010) contributes significantly to the whole-rock composition, even in so-called aphanitic varieties. ii) Volatiles (e.g., $\mathrm{H}_{2} \mathrm{O}$, $\mathrm{CO}_{2}$ ) are exsolved and degassed during kimberlite magma ascent and emplacement (Sparks et al., 2006; Nowicki et al., 2008; Giuliani et al., 2017; Abersteiner et al., 2017b; Shatskiy et al., 2017). iii) Kimberlite rocks are commonly subject to extensive alteration by deuteric (Kopylova et al., 2007; Mitchell, 2008, 2013) and, or, post-emplacement hydrothermal/meteoric fluids (Sparks et al., 2006, 2009; Brooker et al., 2011; Afanasyev et al., 2014; Giuliani et al., 2014, 2017). This low-temperature modification partially overprints the primary kimberlite mineralogy and textures, in which serpentine, brucite and carbonate (e.g., calcite and dolomite) are produced (Clement, 1982; Mitchell, 1986).

\section{Kimberlite composition (current debate)}

During the last 15 years, the perception of kimberlite petrogenesis and the composition of their parental melts have diverged into two contrasting models. The classical view is based on the whole-rock composition of kimberlite rocks and maintains that kimberlites originate from ultramafic/basic and volatile $\left(\mathrm{H}_{2} \mathrm{O}, \mathrm{CO}_{2}\right)$-rich melts (Price et al., 2000; le Roex et al., 2003; Becker \& le Roex, 2006; Kopylova et al., 2007; Mitchell, 2008; Kjarsgaard et al., 2009). Diamond resorption experiments have been used as an indicator of high volatile activity in kimberlite magmas (Fedortchouk et al., 2010; Fedortchouk, 2015). However, these studies did not test these diamond resorption experiments in putative kimberlite magmas, but rather in aqueous solutions. Furthermore these studies were conducted at fixed P-T conditions and neglect the observation that diamonds are brought to the surface whilst being encased in their host mantle xenolith (e.g., peridotite, eclogite). In addition, the presence of phlogopite in 
kimberlites signifies the presence of $\mathrm{H}_{2} \mathrm{O}$ in kimberlite melts. SEM-EDS analyses of phlogopite in the Udachnaya-East kimberlite indicate that it is generally $\mathrm{F}$ - and Cl-poor, and is therefore assumed to be dominantly $\mathrm{H}_{2} \mathrm{O}$-bearing. If the approximate $\mathrm{K}_{2} \mathrm{O} / \mathrm{H}_{2} \mathrm{O}$ in phlogopite is $\sim 2.5 / 3$ and the average $\mathrm{K}_{2} \mathrm{O}$ in bulk- rocks is $1.3 \mathrm{wt} \%$ (Table 2) and all $\mathrm{K}$ in the kimberlite is assumed to have partitioned into phlogopite, then the maximum estimated $\mathrm{H}_{2} \mathrm{O}$ content corresponds to only $0.43-0.52 \mathrm{wt} \%$. It is noteworthy that $\mathrm{K}$ in unserpentinised samples is also partitioned into groundmass alkali-carbonates and chlorides, which suggests that the amount of $\mathrm{H}_{2} \mathrm{O}$ partitioned into phlogopite is lower. Even if there was hypothetically $10 \mathrm{wt} \%$ phlogopite in a kimberlite with $\sim 3.7 \mathrm{wt} \% \mathrm{H}_{2} \mathrm{O}$ (based on compositions from Kopylova et al. 2010), the amount of $\mathrm{H}_{2} \mathrm{O}$ hosted by phlogopite would still correspond to $<1$ wt $\%$.

The alternative view does not consider whole-rock reconstructions to be representative of the parental kimberlite melt, largely due to the hybrid and contaminated nature of kimberlite rocks. This alternative approach relies on recent advancements in petrographic and melt inclusion studies of kimberlites worldwide (Golovin et al., 2003, 2007, 2017a; Kamenetsky et al., 2004, 2009a, 2013, 2014; Abersteiner et al., 2017a, 2017b, 2017c; Giuliani et al., 2017). These studies have suggested that kimberlite melts are depleted in $\mathrm{SiO}_{2}$ and $\mathrm{H}_{2} \mathrm{O}$, and enriched in alkalis, halogens and $\mathrm{CO}_{2}$ (i.e. carbonate) relative to whole-rock compositions. In addition, experimental studies have demonstrated the inability to successfully reproduce kimberlite melts using putative whole-rock kimberlite compositions at magma emplacement conditions (e.g., Sparks et al., 2009; Brooker et al., 2011; Moussallam et al., 2016).

The UE kimberlite has taken the centre stage in the pursuit of genetic reconstructions and is considered the flagship 'least altered' kimberlite for testing the above opposing models. In the following sections we combine petrographic, geochemical and melt inclusion 
data in order to evaluate these two divergent views on the origin of the UE kimberlite and ultimately constrain the parental melt composition.

\section{Unserpentinised and Serpentinised UE Kimberlite}

This study examined coherent and volcaniclastic units of UE kimberlite, which are represented by both unserpentinised and partially serpentinised varieties. Regardless of their textural classification or degree of serpentinisation, both contain texturally and chemically identical olivine populations (Figs $4-7$ ) with similar zoning patterns along with groundmass assemblages of calcite, phlogopite, Fe-Ti-Mg-Al-Cr-spinel (e.g., magnetite/Mg-magnetite, MUM, pleonaste, Cr-spinel), monticellite, perovskite, sulphides (e.g., Fe-Ni-sulphides, djerfisherite) and apatite. Daughter phase assemblages in multiphase melt inclusions hosted in olivine and groundmass minerals (spinel, monticellite, perovskite) in unserpentinised and serpentinised varieties also share a strong degree of similarity (see below). In addition, the whole-rock major element concentrations and primitive mantle normalised trace element patterns are virtually identical (Figs $8 \mathrm{a}-\mathrm{c}$ and 9; Table 2). Although there are numerous key textural, mineralogical and geochemical similarities between unserpentinised and serpentinised UE kimberlite, distinct differences are reflected by:

- Unserpentinised kimberlite contains well-preserved euhedral olivine and abundant Na-K-Cl-rich minerals (i.e. chlorides, S-bearing alkali-carbonates and sodalite) in the groundmass and $\mathrm{H}_{2} \mathrm{O}$-bearing phases are uncommon ( $\leq 4$ vol. \% phlogopite; Table 1$)$.

- Unserpentinised kimberlite exhibits low $\mathrm{H}_{2} \mathrm{O}$ contents $(<0.6 \mathrm{wt} \%)$ and elevated concentrations of $\mathrm{Na}_{2} \mathrm{O}$ (up to $6.2 \mathrm{wt} \%$ ) and $\mathrm{Cl}$ (up to $6.1 \mathrm{wt} \%$; Figs $8 \mathrm{~d}-\mathrm{h}$; Table 2). In contrast, serpentinised samples (i.e. serpentine-iowaite bearing) contain 
moderately variable $\mathrm{H}_{2} \mathrm{O}(>0.6 \mathrm{wt} \%$ and up to $4.5 \mathrm{wt} \%)$, and low $-\mathrm{Na}_{2} \mathrm{O}(<0.5 \mathrm{wt} \%)$, $-\mathrm{Cl}(<0.7 \mathrm{wt} \%)$ and to a lesser extent $\mathrm{K}$ and S concentrations (Figs $8 \mathrm{~d}-\mathrm{h}$; Table 2).

\section{Melt inclusion perspective on kimberlite melt compositions}

Melt inclusion phase assemblages from serpentinised and unserpentinised UE samples are virtually identical and dominated by (in order of relative abundance): Na-K-chlorides, $\mathrm{Ca}$ alkali (Na, K, Sr) carbonates, Fe-Ti-Mg-Cr-Al-spinels, Na-K-sulphates, silicates (tetraferriphlogopite, phlogopite, monticellite, humite), sulphides (Fe-Ni-bearing, djerfisherite), perovskite and apatite (Table 3; Figs. $11-13$ ). The preservation of watersoluble phases in olivine-hosted melt inclusions in serpentinised samples suggests that these inclusions were isolated from the groundmass after their entrapment.

Melt inclusions in monticellite, spinel and perovskite are interpreted to be primary as they are randomly distributed throughout their host grains and located away from fracture systems. The preservation of euhedral monticellite grains and atoll-shaped spinels suggests that these groundmass minerals crystallised in situ. Inclusions of Cr-spinel in olivine (Figs 4b and d) indicate coeval crystallisation with olivine. Previous studies have shown olivine to be the earliest liquidus phase to crystallise in kimberlites along with chromite (Mitchell, 1986, 2008; Fedortchouk \& Canil, 2004). Multi-phase assemblages in primary melt inclusions in magmatic minerals are broadly similar to those in olivine (i.e. alkali-carbonate and chloride dominated; Figs. 14a-g). Therefore, primary melt inclusions provide strong evidence that alkali-carbonates and chlorides were a significant and intrinsic part of the evolved kimberlite melt during groundmass crystallisation. 


\section{Was the Udachnaya-East kimberlite contaminated?}

The UE kimberlite is unique as it contains an exotic alkali-chlorine-sulphur enriched groundmass mineralogy. This has motivated a group of authors to assert that the parental magma was no different to other kimberlites worldwide (i.e. $\mathrm{H}_{2} \mathrm{O}$-rich, ultramafic), but was contaminated by crustal xenoliths (e.g., evaporites) and, or, altered by post-emplacement sedimentary $\mathrm{Na}$-Ca-Cl brines (Kopylova et al., 2013, 2016; Kostrovitskiy et al., 2013). These authors have presented numerous accounts of the preservation of olivine, the low $\mathrm{H}_{2} \mathrm{O}$ contents and origin of high alkalis, chlorine and sulphur in unserpentinised UE kimberlite rocks. Although contamination in the crust may seem like an appealing explanation for the origin of alkali-chlorine-sulphur enrichment in the UE kimberlite, the data to support these contamination models are poorly substantiated and the interpretations contain numerous contradictions (i.e. inconsistencies between successive publications - see below). In addition, previous studies of the UE kimberlite by Kopylova et al. (2016) are not supported by accurate designation of different kimberlite units within the pipe and the results reported are largely inconsistent with our petrographic, geochemical and melt inclusion data.

In the following sections, we demonstrate the problems associated with multiple contamination models and ultimately validate the pristine nature of the unserpentinised UE kimberlite. We combine these data with reliable field documentation of structural and textural features of individual kimberlite units and strict depth and location constraints for each kimberlite unit. A summary of key ideas on the origin of low- $\mathrm{H}_{2} \mathrm{O}$, alkali-chlorine-sulphur enriched unserpentinised kimberlite by Kopylova et al. $(2013,2016)$ and Kostrovitskiy et al. (2013) is presented in Fig. 15.

\section{Was crustal contamination involved?}


The incorporation of country-rock xenoliths is central to the notion that magmatic assimilation caused the elevated $\mathrm{Na}, \mathrm{K}, \mathrm{Cl}$ and $\mathrm{S}$ contents of the UE kimberlite (Kopylova et al., 2013; Kostrovitskiy et al., 2013). A key argument for the non-magmatic origin of salts in the UE kimberlite, in particular large chloride 'nodules' (Kamenetsky et al., 2007; 2014) is that they represent xenoliths that were entrained when the ascending magma intruded carbonate beds hosting 'karst cavities filled with epigenetic halite and gypsum and occasional sedimentary evaporites' (Kopylova et al., 2016; pp. 116). The resulting hybridised kimberlite melt is thought to have formed alkali-carbonates, sodalite and chlorides instead of serpentine (Kopylova et al., 2013; Kostrovitskiy et al., 2013). However, this magmatic assimilation model was later abandoned by Kopylova et al. (2016). These authors instead proposed a mechanical model for the integration and dispersal of crustal xenoliths combined with infiltrating post-emplacement crustal brines (see below) as the most influential factors controlling the composition of the UE kimberlite. Nevertheless, the entrainment of crustal halite xenoliths is contradictory to what the authors previously reported as the UE kimberlite 'does not intersect massive evaporites' (pp. 77 of Kostrovitskiy et al. (2013)). Furthermore, there is no direct evidence for these so-called 'evaporite beds' that the UE kimberlite allegedly intruded through. Such evidence cannot be found in the reports of the open pit or underground mine, or from deep drilling (e.g., parametric and geotechnical drill holes KCC1, 2, 3; see Figs. 1 and 2 of Kamenetsky et al. (2014)).

\section{Origin of alkalis, chlorine and sulphur in melt inclusions}

The entrapment of secondary melt inclusions in olivine in the UE kimberlite has been employed as a principal constraint to support the alkali-chlorine-sulphur enrichment of the parental kimberlite magma (Kamenetsky et al., 2004, 2009a, 2012, 2014). However, 
Kopylova et al. (2013) and Kostrovitskiy et al. (2013) advocated that these secondary inclusions in olivine resulted from explosive and thermal cracking of grains and subsequent entrapment of late residual melts and fluids that equilibrated with kimberlite melts in the subsurface. The enrichment of $\mathrm{Na}, \mathrm{K}, \mathrm{Cl}$ and $\mathrm{S}$ in these olivine-hosted melt inclusions was ascribed to the supposed crustal assimilation by the UE kimberlite magma (Kopylova et al., 2013; Kostrovitskiy et al., 2013). However, Kopylova et al. (2013; pp. 12) highlighted an inherent dilemma in the magmatic assimilation model, as "this should not be appropriate for pyroclastic rocks, since the assimilation could only take place at some deeper level prior to degassing and explosive fragmentation. Only an in situ process that affected kimberlites after or during emplacement could be responsible for the correlation". In a later study by the same authors, an alternative model was introduced for the mechanical incorporation of $\mathrm{Na}-\mathrm{Cl}$ enrichment in olivine-hosted inclusions, where "petrographic observations find such inclusions only in discrete grains in one type of $P K$ (olivine-rich PK; pyroclastic kimberlite), where explosive emplacement fractures olivine clasts and mixes them with salt-rich ash, which could plastically penetrate the cracks and deposit halite along the network of fractures. Halite inclusions do not occur in fractures connecting to the calcite matrix or in CK (coherent kimberlite) olivine." (Kopylova et al., 2016; pp. 132).

Our study clearly demonstrates that alkali-chlorine-sulphur enrichment is not restricted to olivine-hosted secondary inclusions from "pyroclastic" kimberlite, but is present in both CK and VK UE units at wide range of depth intervals (400-520 m). In our view, the notion of 'explosive fracturing' of olivine inadequately explains the development of secondary melt inclusions in CK (i.e. veins and dykes), which did not experience explosive fragmentation. We propose that the development of secondary melt inclusions in olivine was the result of the rapid ascent and decompression of kimberlite magma causing fracturing (Brett et al., 2015) and rounding (or milling) of grains by mechanical abrasion (Reid et al., 
1975; Arndt et al., 2010). Fractures in olivine were then be penetrated by kimberlite melt (Brett et al., 2015) and later sealed during olivine crystallisation (Fedortchouk \& Canil, 2004; Mitchell, 2008; Brett et al., 2009), forming inclusion trails (Kamenetsky et al., 2008; Fig. 16). In addition, primary melt inclusions in spinel, monticellite and perovskite were entrapped in situ during crystallisation of the host-mineral, demonstrating that the crystallising kimberlite melt was enriched (i.e. relative to serpentinised kimberlite) in alkalis, chlorine and sulphur.

Similar alkali-halogen-sulphur enrichment trends have been indicated by melt inclusions in olivine and groundmass minerals (e.g., spinel, perovskite, apatite) in previous studies of the UE kimberlite (Golovin et al., 2003, 2007, 2017a; Kamenetsky et al., 2004, 2009a, 2012; Mernagh et al., 2011) and other localities worldwide (e.g., Gahcho Kué, Jericho; Aaron (Kamenetsky et al., 2009a; Mernagh et al., 2011); Leslie (Abersteiner et al., 2017b; Kamenetsky et al., 2009a), Koala (Kamenetsky et al., 2013) and Roger (Abersteiner et al., 2017c) pipes in Canada; Pipe 1 in Finland (Abersteiner et al., 2017b); Majuagaa dyke in West Greenland (Mernagh et al., 2011; Kamenetsky et al., 2009a); Wesselton pipe (Mernagh et al., 2011), Bultfontein (Giuliani et al., 2017) and Venetia (Abersteiner et al., 2017a) kimberlites in South Africa. Previous experiments on olivine-hosted melt inclusions from Udachnaya-East and other kimberlites worldwide (e.g., Kamenetsky et al., 2004, 2009, 2013, 2014; Golovin et al., 2018) showed that these inclusions typically homogenise at 660 $760{ }^{\circ} \mathrm{C}$ at $1 \mathrm{~atm}$. Upon cooling the melt separates into carbonate and chloride immiscible components and crystallises completely at $200-160{ }^{\circ} \mathrm{C}$.

The study of melt inclusions provides substantial evidence to show that alkalichlorine-sulphur enrichment is an intrinsic feature of variably differentiated kimberlite melts, originating in the mantle. A crustal contamination model is unable to comprehensively 
explain the occurrence of this widespread alkali-chlorine-sulphur enrichment trend in other kimberlites that intruded diverse lithologies in different cratons.

\section{Evidence against Post-Emplacement Alteration by Crustal Brines}

Another major argument against a magmatic origin for alkali-chlorine-sulphur enrichment in the groundmass of the UE kimberlite has been ascribed to interactions with crustal $\mathrm{Na}-\mathrm{Ca}-\mathrm{Cl}$ brines (Kopylova et al., 2013, 2016; Kostrovitskiy et al., 2013). In our view, the preservation of a water-soluble mineralogy in the presence of infiltrating fluids without olivine alteration renders such a contamination model paradoxical. The interaction between the SFUE kimberlite and crustal brines is thought to have impeded serpentinisation (Kostrovitskiy et al., 2013) where "salts and alkali carbonate, rather than secondary serpentine, may have precipitated in breccia voids and replaced original groundmass minerals" (Kopylova et al., 2013; pp. 13). Furthermore, Kopylova et al. (2016) considered that "Na-rich brines dissolve calcite and replace it with fine needles of Na-Ca carbonates" (pp. 126), and "the serpentine of the PKs (pyroclastic kimberlites) matrix $(<3 \%)$ may have been replaced with secondary Na-Ca carbonate" (pp. 132). However, this is in stark contrast to our petrographic observations, which show that olivine maintains near perfect euhedral crystal shapes (Figs 4a and b) with sharp contacts with the groundmass and no textures that indicate secondary replacement by serpentine, calcite or alkali-carbonates.

It was proposed by Kopylova et al. $(2013,2016)$ and Kostrovitskiy et al. (2013) that the Udachnaya-West (UW) and UE intersected different aquifers with different flow rates and compositions. The aquifer in contact with the UW pipe was considered to be $\mathrm{Ca}-\mathrm{Cl}$ in composition and have a low flow rate, whereas the UE pipe intersected a different aquifer that was $\mathrm{Na}-\mathrm{Cl}$ in composition and had a high hydraulic pressure (Kopylova et al., 2013, 
2016). Nevertheless, crustal brines do not adequately explain why there is no similar $\sim 400-$ $500 \mathrm{~m}$ brine-induced 'SFUE' in the UW kimberlite, which is adjacent to UE. Furthermore, these supposed brines represent present day aquifers and cannot take into account $\sim 360 \mathrm{Myr}$ of hydrology in the host sedimentary succession, or shifting brine levels and erosion that has occurred since kimberlite emplacement.

One of the most remarkable features which is inconsistent with secondary alteration by crustal brines is the almost anhydrous $(<0.6 \mathrm{wt} \%)$ geochemical character of the unserpentinised UE kimberlite (Figs 8d and e; Table 2). Kopylova et al. (2013) and Kostrovitskiy et al. (2013) ascribed the low $\mathrm{H}_{2} \mathrm{O}$ of unserpentinised UE kimberlite to highsalinity fluids which resulted from magmatic assimilation. This fluid was considered to have caused a reduction in serpentine stability and the subsequent removal of $\mathrm{H}_{2} \mathrm{O}$ from the melt. Alternatively, Kostrovitskiy et al. (2013) proposed that the absence of serpentine was due a uniquely $\mathrm{H}_{2} \mathrm{O}$-poor primary UE melt, which was previously advocated by Kamenetsky et al. (2007a, 2009a, 2012). In their sudden departure from magmatic assimilation of crustal evaporite xenoliths model, Kopylova et al. (2016) proposed that $\mathrm{H}_{2} \mathrm{O}$ and $\mathrm{CO}_{2}$ were removed during explosive fragmentation of pyroclastic kimberlite, but remained in CK. This contradicts our results on the unserpentinised CK sample K24-04A (Fig. 3), which is essentially anhydrous ( $\leq 0.56 \mathrm{wt} \% \mathrm{H}_{2} \mathrm{O}$ ) and $\mathrm{CO}_{2}$-rich (up to $9.85 \mathrm{wt} \%$; Table 2). Furthermore, the majority of kimberlite samples analysed by Kopylova et al. (2016) were derived from 565 - $585 \mathrm{~m}$ from mine stockpiles. This is below the SFUE depth interval and where modern brines are thought to be present (Fig. 2). Inexplicably, Kopylova et al. (2016) abandoned the term for the 400 - 500m 'SFUE' depth horizon predefined by their earlier studies (Kopylova et al., 2013; Kostrovitskiy et al., 2013). Not only in this study, the 'SFUE' is the only depth horizon where we observed $\mathrm{H}_{2} \mathrm{O}$-poor and alkali-chlorine-sulphur enriched unserpentinised kimberlite. It is noteworthy that the majority (i.e. 24 out of 36) of analyses of 
SFUE kimberlite analysed by Kostrovitskiy et al. (2013) contain $\mathrm{H}_{2} \mathrm{O} \geq 1 \mathrm{wt} \%$ (up to 5.49 wt \%). These geochemical data were not supported by any petrographic images to demonstrate the absence of serpentine in the groundmass and are inconsistent with our results, which show that as $\mathrm{H}_{2} \mathrm{O}$-content increases $(>0.6 \mathrm{wt} \%)$, serpentine starts to appear in the groundmass and increases in abundance with increasing $\mathrm{H}_{2} \mathrm{O}$-content.

We consider that unserpentinised water-soluble alkali-chlorine-sulphur rich groundmass phases could only be preserved if the emplaced kimberlite rocks were unaffected by hydrous alteration. In this study, partially serpentinised samples were derived from $400-$ $420 \mathrm{~m}$, which coincides with the roof of the SFUE, and $480-520 \mathrm{~m}$, which coincides with depths at which modern brines occur $(\sim 510 \mathrm{~m})$. In contrast, unserpentinised samples were derived from $440-500 \mathrm{~m}$, which is above this brine horizon (Fig. 2; also see Figure 2 of Kitayama et al. (2017) and Figure 8 of Alexeev et al. (2007)) and within the SFUE defined by Kopylova et al. (2013) and Kostrovitskiy et al. (2013). Incipient serpentinisation corresponds with the complete absence of water-soluble minerals (e.g., chlorides, S-bearing alkali-carbonates) in the groundmass, which is reflected by significantly lower concentrations of $\mathrm{Na}_{2} \mathrm{O}, \mathrm{K}_{2} \mathrm{O}, \mathrm{Cl}$ and $\mathrm{S}$ (Table 2) than in unserpentinised samples. Chlorine is retained in the groundmass to some extent during serpentinisation where it is fixed in hydrothermal iowaite.

In addition, sulphur isotope and bulk $\mathrm{S}$ analyses have shown that groundmass sulphates and sulphides in the unserpentinised 'salty' UE kimberlite do not conform with an external brine or assimilation of country-rock origin and are instead consistent with late-stage magmatic crystallisation (d'Eyrames et al., 2017; Kitayama et al., 2017). It is well-established that ${ }^{37} \mathrm{Cl} /{ }^{35} \mathrm{Cl}$ ratios in crustal rocks differ only slightly from those in mantle-derived rocks and meteorites (Sharp et al., 2007), whereas sulphur isotope ratios differ significantly. Sulphur isotopes were studied in: (i) VK and CK unserpentinised kimberlite units; (ii) saltbearing sediment samples; (iii) brine containing sulphates from a depth of $750 \mathrm{~m}$ in a drill 
hole $1 \mathrm{~km}$ south of Udachnaya; (iv) hydrothermal sulphides and sulphates from Udachnaya pipe. Kitayama et al. (2017) concluded that, "salty kimberlites from Udachnaya-East were not contaminated by brine infiltration, hydrothermal alteration or the assimilation of known salt-rich country rocks" (pp. 328). Similarly, combined Sr-, Nd- and Pb-isotopic data support a magmatic (i.e. mantle-derived) origin for chlorides and alkali-carbonates from unserpentinised kimberlite rocks (Maas et al., 2005; Kamenetsky et al., 2009a; 2014).

Perhaps the most substantial evidence against crustal brine contamination in the UE kimberlite is from melt inclusions. Primary and secondary inclusions from both unserpentinised and serpentinised samples clearly demonstrate that the kimberlite melt was already enriched in alkalis, chlorine and sulphur (Figs. $11-14$ ) prior to magma solidification and post-emplacement alteration.

\section{Preservation of the unserpentinised Udachnaya-East kimberlite horizon}

The preservation of the unserpentinised kimberlite horizon at Udachnaya-East may have one or several explanations:

(i) Unserpentinised kimberlite units are located in the central part of the pipe and thus are relatively isolated from external groundwater (Fig. 2). Furthermore, the unserpentinised kimberlite horizon is located above and below two modern aquifers (Fig. 2).

(ii) Chlorides are characterised by high thermal conductivity and plastic behaviour which can be self-sealing should fractures develop (Roxburgh, 1987). Chlorides in the UE kimberlite may have formed a protective ductile seal in the kimberlite, which prevented the ingress of water (Kamenetsky et al., 2012). An example of the protective nature of chlorides is in the use of evaporites/rock salt used as disposal sites for high level nuclear waste in Germany 
(Roxburgh, 1987; Kim et al., 1996; Kim \& Grambow, 1999). In the case of Udachnaya-East, it is likely that once this chloride seal is completely breached by groundwater, the kimberlite is prone to alteration (Kamenetsky et al., 2012).

\section{Post-emplacement alteration - Implications for kimberlites worldwide}

The strong degree of petrographic, geochemical and melt inclusion similarity between unserpentinised and serpentinised UE kimberlite suggests that both varieties crystallised from the same magma, but were subject to different post-emplacement processes. Based on our observations of the UE kimberlite, we interpret the unserpentinised samples to represent pristine, unaltered kimberlite. In contrast, partially serpentinised samples were altered by infiltrating post-magmatic external fluids dissolving groundmass alkali-carbonates, chlorides and sulphates and instead forming secondary calcite, serpentine and iowaite. Evidence for an initially chlorine-bearing groundmass of the serpentinised kimberlite is signified by: (i) the preservation of Cl-bearing djerfisherite, which is a relatively stable mineral during postmagmatic alteration (Sharygin et al., 2011), and (ii) secondary iowaite, which resulted from the release of $\mathrm{Mg}-\mathrm{Fe}$ cations during olivine dissolution (Stripp et al., 2006; Evans et al., 2013) combining with dissolved chlorine (Kopylova et al., 2016), which in our view was derived from the groundmass halite and sylvite.

The instability and rapid degradation of alkali-carbonates and chlorides in the UE unserpentinised kimberlite units could be analogous to the freshly erupted Oldoinyo Lengai (Tanzania) natrocarbonatite lavas, where significant mineralogical and compositional changes can occur within days to months upon exposure to the atmosphere (Dawson, 1993; Dawson et al., 1987; Zaitsev \& Keller, 2006). Alkalis are rapidly leached from the carbonatitic rocks during alteration and consequently the only evidence of the initially alkali- 
rich groundmass mineralogy is preserved in melt inclusions. In the case of the Kerimasi (Tanzania; Zaitsev, 2010; Guzmics et al., 2011), Tinderet (Kenya; Zaitsev et al., 2013) and Oka (Canada; Chen et al., 2013) calciocarbonatite complexes, $\mathrm{Na}_{2} \mathrm{O}$ and $\mathrm{K}_{2} \mathrm{O}$ are significantly depleted in bulk-rock compositions but are highly enriched in crystal and melt inclusions hosted by groundmass phases (e.g., magnetite, apatite). The resolution to this paradox is that the emplaced carbonatite rocks crystallised from an initially alkali-rich (or natrocarbonatite) magma, but were subjected to extensive weathering and, or, metasomatism (Zaitsev, 2010; Guzmics et al., 2011; Chen et al., 2013; Zaitsev et al., 2013). A similar trend of alkali, halogen and sulphur enrichment is recorded by melt inclusions in olivine and groundmass minerals in our samples, as well as in other studies of the UE kimberlite and other localities worldwide (see above). By analogy with the alteration processes of natrocarbonatites, we consider that it is likely that alkalis, chlorine and sulphur were significantly leached from the kimberlites during syn- and, or, post-emplacement alteration.

Although Oldoinyo Lengai natrocarbonatite lavas and the reconstructed melt inclusion compositions from kimberlites are inferred to be analogous, kimberlites and carbonatites generally experience different styles of eruption. In many cases, kimberlite volcanoes have highly dynamic eruptions (e.g., Skinner \& Marsh, 2004; Sparks et al., 2006) with explosive flows through conduits, but may also erupt weakly and form lava flows (Brown et al., 2012). In contrast, the Oldoinyo Lengai natrocarbonatite lavas erupt effusively (Keller \& Krafft, 1990; Kervyn et al., 2008). In our view, the presence of entrained mantle silicates (e.g., olivine, orthopyroxene) in kimberlites is fundamental to $\mathrm{CO}_{2}$ degassing and ultimately to their rapid ascent, where assimilation of silicates and decompression can cause a catastrophic reduction in carbon dioxide solubility (Brooker et al., 2011; Russell et al., 2012; Kamenetsky et al., 2015; Moussallam et al., 2016) in the melt, or olivine may react with the carbonate component of the melt upon emplacement to liberate $\mathrm{CO}_{2}($ Abersteiner et al., 
2017b). The absence of mantle silicates in Oldoinyo Lengai means that such volatile degassing or decarbonation reaction scenarios are unlikely.

Abundant alkali-chlorine-bearing multiphase inclusions hosted in groundmass calcite are primary in both serpentinised and unserpentinised samples (Fig. 14h). Groundmass calcite is generally considered to be primary magmatic (Armstrong et al., 2004; Dawson, 1980; Giuliani et al., 2014; Mitchell, 1986; Wilson et al., 2007), but has also been ascribed to external post-magmatic fluids (Armstrong et al., 2004; Exley \& Jones, 1983; Giuliani et al., 2014, 2017; Podvysotskiy, 1985). The remarkable compositional similarity of inclusions in magmatic groundmass calcite to melt inclusions hosted in olivine, monticellite, spinel and perovskite suggests that these calcite-hosted inclusions represent relics of the late-stage differentiated kimberlite melt that evolved towards incompatible element enriched, carbonatitic compositions, from which $\mathrm{Si}$ and $\mathrm{Al}$ were removed due to fractional crystallisation (i.e. olivine, spinel, phlogopite formation).

\section{CONCLUSIONS}

Although the composition and origin of the proto-kimberlite melt is beyond the scope of this study, we consider alkali-chlorine-sulphur enrichment (i.e. relative to serpentinised kimberlite) in melt inclusions to be a function of kimberlite melt evolution. Progressive crystallisation of silicate phases (e.g., olivine) during groundmass crystallisation removed $\mathrm{SiO}_{2}$ and $\mathrm{MgO}$ from the melt, resulting in a melt shift towards carbonatitic compositions that concentrated alkalis, chlorine and sulphur. This differentiation process ultimately crystallised alkali-carbonates, chlorides, sulphates and sulphides in the UE kimberlite groundmass. The initial $\mathrm{H}_{2} \mathrm{O}$-contents of the parental UE kimberlite magma is ultimately dependent on whether serpentine is interpreted to be a late-magmatic (i.e. crystallises from deuteric fluids) phase or 
secondary product resulting from alteration. In our view, these water-soluble alkali- and chlorine-bearing phases could only be preserved if the parental magma was $\mathrm{H}_{2} \mathrm{O}$-poor. This implies that serpentine and iowaite in the Udachnaya-East kimberlite were formed as a secondary product (i.e. post-magmatic) due to infiltrating external fluids.

Based on the composition of the unserpentinised UE kimberlite groundmass and melt inclusions reported here, we suggest that the unserpentinised UE kimberlite is pristine and crystallised from an $\mathrm{H}_{2} \mathrm{O}$-poor, Si-Na-K-Cl-S-bearing, carbonate-rich melt, which could be analogous to the modern natrocarbonatite lavas observed at Oldoinyo Lengai. These results support the notion that parental proto-kimberlite melt for the Udachnaya-East was essentially anhydrous, $\mathrm{SiO}_{2}$-poor and was dominated by carbonates and enriched in lithophile trace elements, alkalis ( $\mathrm{Na}, \mathrm{K})$, halogens $(\mathrm{Cl})$ and sulphur.

\section{ACKNOWLEDGEMENTS}

This study forms part of A.A's Ph.D and was supported by an Australian Postgraduate Award (APA). This work has benefitted from comments by two reviewers, Geoffrey Howarth and Lucy Porritt, and efficient editorial handling by James Mungall.

\section{FUNDING}

This work was supported by Australian Research Council (ARC) Discovery grant (DP130100257, 2013-2015) and University of Tasmania (New Star Professorship, 20102014) to V. Kamenetsky. AVG was supported by Russian state assignment project No. 03302016-0006. 


\section{REFERENCES}

Abersteiner, A., Giuliani, A., Kamenetsky, V. S., Phillips, D. (2017a). Petrographic and meltinclusion constraints on the petrogenesis of a magmaclast from the Venetia kimberlite cluster, South Africa. Chemical Geology 455, 331-341.

Abersteiner, A., Kamenetsky, V. S., Graham Pearson, D., Kamenetsky, M., Goemann, K., Ehrig, K., Rodemann, T. (2017b). Monticellite in group-I kimberlites: Implications for evolution of parental melts and post-emplacement $\mathrm{CO}_{2}$ degassing. Chemical Geology 478, $78-88$.

Abersteiner, A., Kamenetsky, V. S., Kamenetsky, M., Goemann, K., Ehrig, K., Rodemann, T. (2017c). Significance of halogens (F, Cl) in kimberlite melts: Insights from mineralogy and melt inclusions in the Roger pipe (Ekati, Canada). Chemical Geology 478, 148-163.

Afanasyev, A. A., Melnik, O., Porritt, L., Schumacher, J. C., Sparks, R. S. J. (2014).

Hydrothermal alteration of kimberlite by convective flows of external water. Contributions to Mineralogy and Petrology 168, 1038-1055.

Agashev, A. M., Pokhilenko, N. P., Cherepanova, Y. V., Golovin, A. V. (2010). Geochemical evolution of rocks at the base of the lithospheric mantle: Evidence from study of xenoliths of deformed peridotites from kimberlite of the Udachnaya pipe. Doklady Earth Sciences $\mathbf{4 3 2}$, 746-749.

Alexeev, S. V., Alexeeva, L. P., Borisov, V. N., Shouakar-Stash, O., Frape, S. K., Chabaux, F., Kononov, A. M. (2007). Isotopic composition (H, O, Cl, Sr) of ground brines of the Siberian Platform. Russian Geology and Geophysics 48, 225-236.

Alexseev, S.V., 2009. Cryogeological Systems of the Yakutian Diamondiferous Province. Academic Publishing House “GEO”, Novosibirsk (319 pp.). 
Armstrong, J. P., Wilson, M., Barnett, R. L., Nowicki, T., Kjarsgaard, B. A. (2004).

Mineralogy of primary carbonate-bearing hypabyssal kimberlite, Lac de Gras, Slave

Province, Northwest Territories, Canada. Lithos 76, 415-433.

Arndt, N. T., Guitreau, M., Boullier, A. M., le Roex, A., Tommasi, A., Cordier, P., Sobolev, A. (2010). Olivine, and the Origin of Kimberlite. Journal of Petrology 51, 573-602.

Becker, M., le Roex, A. P. (2006). Geochemistry of South African On- and Off-craton, Group I and Group II Kimberlites: Petrogenesis and Source Region Evolution. Journal of Petrology 47, 673-703.

Brett, R. C., Russell, J. K., Moss, S. (2009). Origin of olivine in kimberlite: Phenocryst or impostor? Lithos 112S, 201-212.

Brett, R. C., Russell, J. K., Andrews, G. D. M., Jones, T. J. (2015). The ascent of kimberlite: Insights from olivine. Earth and Planetary Science Letters 424, 119-131.

Brooker, R., Sparks, R., Kavanagh, J., Field, M. (2011). The volatile content of hypabyssal kimberlite magmas: some constraints from experiments on natural rock compositions.

Bulletin of Volcanology 73, 959-981.

Brown, R. J., Manya, S., Buisman, I., Fontana, G., Field, M., Mac Niocaill, C., Sparks, R. S. J., Stuart, F. M. (2012). Eruption of kimberlite magmas: physical volcanology, geomorphology and age of the youngest kimberlitic volcanoes known on earth (the Upper Pleistocene/Holocene Igwisi Hills volcanoes, Tanzania). Bulletin of Volcanology 74, 16211643.

Buse, B., Schumacher, J., Sparks, R., Field, M. (2010). Growth of bultfonteinite and hydrogarnet in metasomatized basalt xenoliths in the B/K9 kimberlite, Damtshaa, Botswana: insights into hydrothermal metamorphism in kimberlite pipes. Contributions to Mineralogy and Petrology 160, 533-550. 
Chen, W., Kamenetsky, V. S., Simonetti, A. (2013). Evidence for the alkaline nature of parental carbonatite melts at Oka complex in Canada. Nature Communications 4, 2687.

Clement, C. R. (1982). A comparative geological study of some major kimberlite pipes in the Northern Cape and Orange Free State. Cape Town: University of Cape Town, 431.

Clement, C. R., Skinner, E. M. W., Smith, B. H. S. (1984). Kimberlite Redefined. University of Chicago Press, 223.

d'Eyrames, E., Thomassot, E., Kitayama, Y., Golovin, A., Korsakov, A., Ionov, D. (2017). A mantle origin for sulfates in the unusual "salty" Udachnaya-East kimberlite from sulfur abundances, speciation and their relationship with groundmass carbonates. Bulletin of the Geological Society of France 188, 1-11.

Dawson, J. B. (1980). Kimberlites and their xenoliths. New York: Springer-Verlag.

Dawson, J. B. (1993). A supposed sövite from Oldoinyo Lengai, Tanzania: Result of extreme ateration of alkali carbonatite lava. Mineralogical Magazine 57, 93-101.

Dawson, J. B., Garson, M. S., Roberts, B. (1987). Altered former alkalic carbonatite lava from Oldoinyo Lengai, Tanzania: inferences for calcite carbonatite lavas. Geology 15, 765768.

Doucet, L. S., Ionov, D. A., Golovin, A. V., Pokhilenko, N. P. (2012). Depth, degrees and tectonic settings of mantle melting during craton formation: inferences from major and trace element compositions of spinel harzburgite xenoliths from the Udachnaya kimberlite, central Siberia. Earth and Planetary Science Letters 359-360, 206-218.

Egorov, K.N., Kornilova, V.P., Safronov, A.F., Filippov, N.D., 1986. Micaceous kimberlite from the Udachnaya-East pipe. Doklady of the Academy of Sciences of the USSR 291 (1), 199-202 (In Russian).

Evans, B. W., Hattori, K., Baronnet, A. (2013). Serpentinite: What, Why, Where? Elements 9, 99-106. 
Exley, R. A. \& Jones, A. P. (1983). 87Sr/86Sr in kimberlitic carbonates by ion microprobe: Hydrothermal alteration, crustal contamination and relation to carbonatite. Contributions to Mineralogy and Petrology 83, 288-292.

Fedortchouk, Y. \& Canil, D. (2004). Intensive Variables in Kimberlite Magmas, Lac de Gras, Canada and Implications for Diamond Survival. Journal of Petrology 45, 1725-1745. Fedortchouk, Y., Matveev, S., Carlson, J. A. (2010). $\mathrm{H}_{2} \mathrm{O}$ and $\mathrm{CO}_{2}$ in kimberlitic fluid as recorded by diamonds and olivines in several Ekati Diamond Mine kimberlites, Northwest Territories, Canada. Earth and Planetary Science Letters 289, 549-559. Fedortchouk, Y. (2015). Diamond resorption features as a new method for examining conditions of kimberlite emplacement. Contributions to Mineralogy and Petrology 170, $36 \mathrm{pp}$.

Giuliani, A., Phillips, D., Kamenetsky, V. S., Fiorentini, M. L., Farquhar, J., Kendrick, M. A. (2014). Stable isotope (C, O, S) compositions of volatile-rich minerals in kimberlites: A review. Chemical Geology 374-375, 61-83.

Giuliani, A., Soltys, A., Phillips, D., Kamenetsky, V. S., Maas, R., Goemann, K., Woodhead, J. D., Drysdale, R., Griffin, W. L. (2017). The final stages of kimberlite petrogenesis: Petrography, mineral chemistry, melt inclusions and Sr-C-O isotope geochemistry of the Bultfontein kimberlite (Kimberley, South Africa). Chemical Geology 455, 342-356. Golovin, A.V., Sharygin, V.V., Pokhilenko, N.P., Mal'kovets, V.G., Kolesov, B.A., Sobolev, N.V., (2003). Secondary melt inclusions in olivine from unaltered kimberlites of the Udachnaya-East pipe, Yakutia. Doklady Earth Sciences 388, 93-96.

Golovin, A. V., Sharygin, V. V., Pokhilenko, N. P. (2007). Melt inclusions in olivine phenocrysts in unaltered kimberlites from the Udachnaya-East pipe, Yakutia: Some aspects of kimberlite magma evolution during late crystallization stages. Petrology 15, 168-183. 
Golovin, A. V., Sharygin, I. S., Korsakov, A. V. (2017a). Origin of alkaline carbonates in kimberlites of the Siberian craton: Evidence from melt inclusions in mantle olivine of the Udachnaya-East kimberlite. Chemical Geology 455, 357-375.

Golovin, A. V., Goryainov, S. V., Kokh, S. N., Sharygin, I. S., Rashchenko, S. V., Kokh, K. A., Sokol, E. V., Devyatiyarova, A. S. (2017b). The application of Raman spectroscopy to djerfisherite identification. Journal of Raman Spectroscopy 48, 1574-1582.

Golovin, A. V., Sharygin, I. S., Kamenetsky, V. S., Korsakov, A. V., Yaxley, G. M. (2018). Alkali-carbonate melts from the base of cratonic lithospheric mantle: links to kimberlites. Chemical Geology 483, 261-274.

Guzmics, T., Mitchell, R. H., Szabó, C., Berkesi, M., Milke, R., Abart, R. (2011). Carbonatite melt inclusions in coexisting magnetite, apatite and monticellite in Kerimasi calciocarbonatite, Tanzania: melt evolution and petrogenesis. Contributions to Mineralogy and Petrology 161, 177-196.

Hunter, R. H. \& Taylor, L. A. (1982). Instability of garnet from the mantle: glass as evidence of metasomatic melting. Geology 10, $617-620$.

Ionov, D. A., Doucet, L. S., Ashchepkov, I. V. (2010). Composition of the Lithospheric Mantle in the Siberian Craton: New Constraints from Fresh Peridotites in the Udachnaya-East Kimberlite. Journal of Petrology 51, 2177-2210.

Kamenetsky, M. B., Sobolev, A. V., Kamenetsky, V. S., Maas, R., Danyushevsky, L. V., Thomas, R., Pokhilenko, N. P., Sobolev, N. V. (2004). Kimberlite melts rich in alkali chlorides and carbonates: A potent metasomatic agent in the mantle. Geology 32, 845-848. Kamenetsky, V. S., Kamenetsky, M. B., Sharygin, V. V., Faure, K., Golovin, A. V. (2007a). Chloride and carbonate immiscible liquids at the closure of the kimberlite magma evolution (Udachnaya-East kimberlite, Siberia). Chemical Geology 237, 384-400. 
Kamenetsky, V. S., Kamenetsky, M. B., Sharygin, V. V., Golovin, A. V. (2007b). Carbonatechloride enrichment in fresh kimberlites of the Udachnaya-East pipe, Siberia: A clue to physical properties of kimberlite magmas? Geophysical Research Letters 34, L09316. doi.org/10.1029/2007GL029389.

Kamenetsky, V. S., Kamenetsky, M. B., Sobolev, A. V., Golovin, A. V., Demouchy, S., Faure, K., Sharygin, V. V., Kuzmin, D. V. (2008). Olivine in the Udachnaya-East Kimberlite (Yakutia, Russia): Types, Compositions and Origins. Journal of Petrology 49, 823-839. Kamenetsky, V. S., Kamenetsky, M. B., Weiss, Y., Navon, O., Nielsen, T. F. D., Mernagh, T. P. (2009a). How unique is the Udachnaya-East kimberlite? Comparison with kimberlites from the Slave Craton (Canada) and SW Greenland. Lithos 112S, 334-346.

Kamenetsky, V. S., Maas, R., Kamenetsky, M. B., Paton, C., Phillips, D., Golovin, A. V., Gornova, M. A. (2009b). Chlorine from the mantle: Magmatic halides in the Udachnaya-East kimberlite, Siberia. Earth and Planetary Science Letters 285, 96-104.

Kamenetsky, V. S., Kamenetsky, M. B., Golovin, A. V., Sharygin, V. V., Maas, R. (2012). Ultrafresh salty kimberlite of the Udachnaya-East pipe (Yakutia, Russia): A petrological oddity or fortuitous discovery? Lithos 152, 173-186.

Kamenetsky, V. S., Grutter, H., Kamenetsky, M. B., Goemann, K. (2013). Parental carbonatitic melt of the Koala kimberlite (Canada): Constraints from melt inclusions in olivine and Cr-spinel, and groundmass carbonate. Chemical Geology 353, 96-111.

Kamenetsky, V. S., Golovin, A. V., Maas, R., Giuliani, A., Kamenetsky, M. B., Weiss, Y. (2014). Towards a new model for kimberlite petrogenesis: Evidence from unaltered kimberlites and mantle minerals. Earth-Science Reviews 139, 145-167.

Kamenetsky, V. S. \& Yaxley, G. M. (2015). Carbonate-silicate liquid immiscibility in the mantle propels kimberlite magma ascent. Geochimica et Cosmochimica Acta 158, 48-56. 
Keller, J., Krafft, M. (1990). Effusive natrocarbonatite activity of Oldoinyo Lengai, June 1988. Bulletin of Volcanology 52, 629-645.

Kervyn, M., Ernst, G. G. J., Klaudius, J., Keller, J., Kervyn, F., Mattsson, H. B., Belton, F., Mbede, E., Jacobs, P. (2008). Voluminous lava flows at Oldoinyo Lengai in 2006:

chronology of events and insights into the shallow magmatic system. Bulletin of Volcanology 70, 1069-1086.

Kharkiv, A. D., Zuenko, V. V., Zinchuk, N. N., Kryuchkov, A. I., Ukhanov, A. V., Bogatykh, M. M. (1991). Petrochemistry of kimberlites. Nedra, Moscow (304 pp.).

Kharkiv, A.D., Zinchuk, N.N., Kruchkov, A.I. (1998). Primary Diamond Deposits of the World (in Russian). Nedra, Moscow (555 pp.).

Kim, J. I., Grompper, K. D., Closs, K. D., Kessler, G., Faude, D. (1996). German approaches to closing the nuclear fuel cycle and final disposal of HLW. Journal of Nuclear Materials 238, $1-10$.

Kim, J. I., Grambow, B. (1999). Geochemical assessement of actinide isolation in a German salt repository environment. Engineering Geology 52, 221-230.

Kinny, P. D., Griffin, B. J., Heaman, L. M., Brakhfogel, F. F., Spetsius, Z. V. (1997). SHRIMP U-Pb ages of perovskite from Yakutian kimberlites. Geologiya i geofizika 38, 9199.

Kitayama, Y., Thomassot, E., Galy, A., Golovin, A., Korsakov, A., d'Eyrames, E., Assayag, N., Bouden, N., Ionov, D. (2017). Co-magmatic sulfides and sulfates in the Udachnaya-East pipe (Siberia): A record of the redox state and isotopic composition of sulfur in kimberlites and their mantle sources. Chemical Geology 455, 315-330.

Kjarsgaard, B. A., Pearson, D. G., Tappe, S., Nowell, G. M., Dowall, D. P. (2009). Geochemistry of hypabyssal kimberlites from Lac de Gras, Canada: Comparisons to a global database and applications to the parent magma problem. Lithos 112S, 236-248. 
Kopylova, M. G., Matveev, S., Raudsepp, M. (2007). Searching for parental kimberlite melt. Geochimica et Cosmochimica Acta 71, 3616-3629.

Kopylova, M. G., Mogg, T. (2010). Mineralogy of the Snap Lake kimberlite, Northwest Territories, Canada, and compositions of phlogopite as records of its crystallization. Canadian Mineralogist 48, 549-570.

Kopylova, M. G., Kostrovitsky, S. I., Egorov, K. N. (2013). Salts in southern Yakutian kimberlites and the problem of primary alkali kimberlite melts. Earth-Science Reviews 119, $1-16$.

Kopylova, M. G., Gaudet, M., Kostrovitsky, S. I., Polozov, A. G., Yakovlev, D. A. (2016). Origin of salts and alkali carbonates in the Udachnaya East kimberlite: Insights from petrography of kimberlite phases and their carbonate and evaporite xenoliths. Journal of Volcanology and Geothermal Research 327, 116-134.

Kostrovitskiy, S. I., Kopylova, M. G., Egorov, K. N., Yakovlev, D. A. (2013). The Exceptionally Fresh Udachnaya-East Kimberlite: Evidence for Brine and Evaporite Contamination. In: Pearson, D.G., et al. (Eds.), Proceedings of the 10th International Kimberlite Conference, 75-91.

le Roex, A. P., Bell, D. R., Davis, P. (2003). Petrogenesis of Group I Kimberlites from Kimberley, South Africa: Evidence from Bulk-rock Geochemistry. Journal of Petrology 44, $2261-2286$.

Maas, R., Kamenetsky, M. B., Sobolev, A. V., Kamenetsky, V. S., Sobolev, N. V. (2005). Sr, $\mathrm{Nd}$, and $\mathrm{Pb}$ isotope evidence for a mantle origin of alkali chlorides and carbonates in the Udachnaya kimberlite, Siberia. Geology 33, 549-552.

Marshintsev, V.K. (1986). Vertical Heterogeneity of Kimberlite Bodies in Yakutia. Nauka, Novosibirsk (239 pp.). 
Marshintsev, V.K., Migalkin, K.N., Nikolaev, N.C., Barashkov, Y.P., (1976). Unaltered kimberlite of the Udachnaya East pipe. Transactions (Doklady) of the USSR Academy of Sciences 231, 961-964.

Mernagh, T. P., Kamenetsky, V. S., Kamenetsky, M. B. (2011). A Raman microprobe study of melt inclusions in kimberlites from Siberia, Canada, SW Greenland and South Africa. Spectrochimica Acta Part A: Molecular and Biomolecular Spectroscopy 80, 82-87. Mikhailenko, D. S., Korsakov, A. V., Rashchenko, S. V., Seryotkin, Y, V., Belakovskiy, D. I., Golovin, A. V. (2018). Kuliginite: A new hydroxychloride mineral from Udachnaya kimberlite pipe, Yakutia. American Mineralogist (IN PRESS). Mitchell, R. H. (1986). Kimberlites: Mineralogy, Geochemistry and Petrology. New York: Plenum Publishing Company.

Mitchell, R. H. (2008). Petrology of hypabyssal kimberlites: Relevance to primary magma compositions. Journal of Volcanology and Geothermal Research 174, 1-8.

Mitchell, R. H. (2013). Oxygen isotope studies of serpentine in kimberlite. Proceedings of the 10th International Kimberlite Conference. Bangalore: Geological Society of India, 1-12. Moussallam, Y., Morizet, Y., Gaillard, F. (2016). $\mathrm{H}_{2} \mathrm{O}-\mathrm{CO}_{2}$ solubility in low $\mathrm{SiO}_{2}$-melts and the unique mode of kimberlite degassing and emplacement. Earth and Planetary Science Letters 447, 151-160.

Nowicki, T., Porritt, L., Crawford, B., Kjarsgaard, B. (2008). Geochemical trends in kimberlites of the Ekati property, Northwest Territories, Canada: Insights on volcanic and resedimentation processes. Journal of Volcanology and Geothermal Research 174, 117-127. O'Brien, H. E. \& Tyni, M. (1999). Mineralogy and Geochemistry of Kimberlites and Related Rocks from Finland. In: Gurney, J.J., Gurney, J.L., Pascoe, M.D., Richardson, S.H. (Eds.), Proceedings of the VIIth International Kimberlite Conference. Red Roof Design, Cape Town, pp. $625-636$. 
Pearson, D. G., Shirey, S. B., Carlson, R. W., Boyd, F. R., Pokhilenko, N. P. \& Shimizu, N. (1995). Re-Os, Sm-Nd, and Rb-Sr isotope evidence for thick Archaean lithospheric mantle beneath the Siberian craton modified by multistage metasomatism. Geochimica et Cosmochimica Acta 59, 959-977.

Pearson, D. G., Brenker, F. E., Nestola, F., McNeill, J., Nasdala, L., Hutchison, M. T., Matveev, S., Mather, K., Silversmit, G., Schmitz, S., Vekemans, B., Vincze, L. (2014). Hydrous mantle transition zone indicated by ringwoodite included within diamond. Nature 507, 221-224.

Podvysotskiy, V. T. (1985). Serpentine-carbonate mineralization in kimberlites. International Geology Review 27, 810-823.

Price, S. E., Russell, J. K., Kopylova, M. G. (2000). Primitive Magma From the Jericho Pipe, N.W.T., Canada: Constraints on Primary Kimberlite Melt Chemistry. Journal of Petrology 41, 789-808.

Reid, A. M., Donaldson, C. H., Dawson, J. B., Brown, R. W., Ridley, W. I. (1975). The Igwisi Hills extrusive "kimberlites". Physics and Chemistry of the Earth 9, 199-218. Roedder, E. (1984). Fluid Inclusions. Mineralogical Society of America, Reviews in Mineralogy Vol. 12.

Roeder, P. L. \& Schulze, D. J. (2008). Crystallization of Groundmass Spinel in Kimberlite. Journal of Petrology 49, 1473-1495.

Roxburgh, I. S. (1987). The suitability of evaporites as HLW repositories. In: Geology of High-Level Nuclear Waste Disposal. Springer, Dordrecht. Russell, J. K., Porritt, L. A., Lavallee, Y., Dingwell, D. B. (2012). Kimberlite ascent by assimilation-fuelled buoyancy. Nature 481, 352-356.

Safonov, O. G., Chertkova, N. V., Perchuk, L. L., Litvin, Y. A. (2009). Experimental model for alkalic chloride-rich liquids in the upper mantle. Lithos 112, 260-273. 
Safonov, O. G., Kamenetsky, V. S., Perchuk, L. L. (2010). Links between Carbonatite and Kimberlite Melts in Chloride-Carbonate-Silicate Systems: Experiments and Application to Natural Assemblages. Journal of Petrology 52, 1307-1331.

Scott Smith, B. H., Nowicki, T. E., Russell, J. K., Webb, K. J., Mitchell, R. H., Hetman, C. M., Harder, M., Skinner, E. M. W., Robey, J. A. (2013). Kimberlite Terminology and Classification. Proceedings of 10th International Kimberlite Conference, 1.

Sharygin, V. V., Golovin, A. V., Pokhilenko, N. P., Sobolev, N. V. (2003). Djerfisherite in unaltered kimberlites of the Udachnaya-East pipe, Yakutia. Doklady Earth Sciences 390, 554-557.

Sharp, Z. D., Barnes, J. D., Brearley, A. J., Fischer, T., Chaussidon, M., Kamenetsky, V. S. (2007). Chlorine isotope homogeneity of the mantle, crust and carbonaceous chondrites. Nature 446, 1062-1065.

Sharygin, V. V., Kamenetsky, V. S., Kamenetsky, M. B. (2008). Potassium sulfides in kimberlite-hosted chloride-'nyerereite' and chloride clasts of the Udachnaya-East pipe, Yakutia, Russia. Canadian Mineralogist 46, 1079-1095.

Sharygin, I. S., Golovin, A. V., Pokhilenko, N. P. (2011). Djerfisherite in Kimberlites of the Kuoikskoe field as an indicator of enrichment of Kimberlite melts in chlorine. Doklady Earth Sciences 436, 301-307.

Sharygin, I. S., Litasov, K. D., Shatskiy, A., Golovin, A. V., Ohtani, E., Pokhilenko, N. P., (2015). Melting phase relations of the Udachnaya-East Group-I kimberlite at 3.0-6.5 GPa: experimental evidence for alkali-carbonatite composition of primary kimberlite melts and implications for mantle plumes. Gondwana Research 28, 1391 -1414.

Sharygin, I. S., Litasov, K. D., Shatskiy, A., Safonov, O. G., Golovin, A. V., Ohtani, E., Pokhilenko, N. P. (2017). Experimental constraints on orthopyroxene dissolution in alkali 
carbonate melts in the lithospheric mantle: Implications for kimberlite melt composition and magma ascent. Chemical Geology 455, 44-56.

Shatskiy, A., Litasov, K. D., Sharygin, I. S., Ohtani, E. (2017). Composition of primary kimberlite melt in a garnet lherzolite mantle source: constraints from melting phase relations in anhydrous Udachnaya-East kimberlite with variable $\mathrm{CO}_{2}$ content at $6.5 \mathrm{GPa}$. Gondwana Research 45, 208-227.

Shee, S. R. (1985). The Petrogenesis of the Wesselton Mine kimberlites, Kimberley, Cape Province, RSA. Unpublished Ph.D. thesis, University of Cape Town, South Africa. Skinner, E. M. W., Marsh, J. S. (2004). Distinct kimberlite pipe classes with contrasting eruption processes. Lithos 76, 183-200.

Smith, C. B., Sims, K., Chimuka, L., Duffin, A., Beard, A. D., Townend, R. (2004). Kimberlite metasomatism at Murowa and Sese pipes, Zimbabwe. Lithos 76, 219-232. Soltys, A., Giuliani, A., Phillips, D., Kamenetsky, V. S., Maas, R., Woodhead, J., Rodemann, T. (2016). In-situ assimilation of mantle minerals by kimberlitic magmas — Direct evidence from a garnet wehrlite xenolith entrained in the Bultfontein kimberlite (Kimberley, South Africa). Lithos 256-257, 182-196.

Sparks, R. S. J., Baker, L., Brown, R. J., Field, M., Schumacher, J., Stripp, G., Walters, A. (2006). Dynamical constraints on kimberlite volcanism. Journal of Volcanology and Geothermal Research 155, 18-48.

Sparks, R. S. J., Brooker, R. A., Field, M., Kavanagh, J., Schumacher, J. C., Walter, M. J., White, J. (2009). The nature of erupting kimberlite melts. Lithos 112S, 429-438.

Stone, R. S., Luth, R. W., (2017). Orthopyroxene survival in deep carbonatite melts: implications for kimberlites. Contributions to Mineralogy \& Petrology 171, 1-9. 
Stripp, G. R., Field, M., Schumacher, J. C., Sparks, R. S. J., Cressey, G. (2006). Postemplacement serpentinization and related hydrothermal metamorphism in a kimberlite from Venetia, South Africa. Journal of Metamorphic Geology 24, 515-534.

Sun, S.-S. \& McDonough, W. F. (1989). Chemical and isotopic systematics of oceanic basalts: implications for mantle composition and processes. In: Saunders, A.D., Norry, M.J. (Eds.), Magmatism in the Ocean Basins. Geological Society Special Publication, London, 313-345.

Tappe, S., Pearson, D. G., Nowell, G., Nielsen, T., Milstead, P., Muehlenbachs, K. (2011). A fresh isotopic look at Greenland kimberlites: Cratonic mantle lithosphere imprint on deep source signal. Earth and Planetary Science Letters 305, 235-248.

Tappe, S., Graham Pearson, D., Kjarsgaard, B. A., Nowell, G., Dowall, D. (2013). Mantle transition zone input to kimberlite magmatism near a subduction zone: Origin of anomalous $\mathrm{Nd}-\mathrm{Hf}$ isotope systematics at Lac de Gras, Canada. Earth and Planetary Science Letters 371-372, 235-251.

Tappe, S., Brand, N. B., Stracke, A., van Acken, D., Liu, C.-Z., Strauss, H., Wu, F.-Y., Luguet, A., Mitchell, R. H. (2016). Plates or plumes in the origin of kimberlites: U/Pb perovskite and Sr-Nd-Hf-Os-C-O isotope constraints from the Superior craton (Canada). Chemical Geology 455, 57-83.

Vasilenko, V. B., Zinchuk, N. N., Krasavchikov, V. O., Kuznetsova, L. G., Khlestov, V. V., Volkova, N. I. (2002). Diamond potential estimation based on kimberlite major element chemistry. Journal for Geochemical Exploration 76, 93-112.

Wilson, M. R., Kjarsgaard, B. A., Taylor, B. (2007). Stable isotope composition of magmatic and deuteric carbonate phases in hypabyssal kimberlite, Lac de Gras field, Northwest Territories, Canada. Chemical Geology 242, 435-454. 
Zaitsev, A. \& Keller, J. (2006). Mineralogical and chemical transformation of Oldoinyo Lengai natrocarbonatites, Tanzania. Lithos 91, 191-207.

Zaitsev, A. N. (2010). Nyerereite from calcite carbonatite at the Kerimasi Volcano, Northern Tanzania. Geology Of Ore Deposits 6, 630-640.

Zaitsev, A., Wenzel, T., Vennemann, T., Markl, G. (2013). Tinderet volcano, Kenya: an altered natrocarbonatite locality? Mineralogical Magazine 77, 213-226.

Zinchuk, N.N., Spetsius, Z.V., Zuenko, V.V., Zuev, V.M., 1993. The Udachnaya Kimberlite

Pipe (In Russian). Publishing House of the Novosibirsk University, Novosibirsk (147 pp.).

\section{FIGURE CAPTIONS}

Figure 1. Map of the Siberian Platform showing the location of the Udachnaya kimberlite and other kimberlite fields after Pearson et al. (1995) and Kamenetsky et al. (2008).

Figure 2. Geological cross-section of the Udachnaya kimberlite pipes (edited after Golovin et al. (2017)). Units $1-4=$ western body, which contains volcaniclastic kimberlite (units $1-3$, which have well defined boundaries) and veins of coherent kimberlite (4). Units $5-10=$ eastern body, which consists of volcaniclastic kimberlite (units 5-9, which have well defined boundaries) and veins of coherent kimberlite (10). Volcaniclastic kimberlite unit 9 can be divided into two types (a) and (b). Although the textural and structural characteristics of these types are identical, there are various changes in groundmass mineralogy that occur at different depths. Volcaniclastic kimberlite unit 9: (a) Green = unserpentinised 'fresh' kimberlite (see Kamenetsky et al., 2012, 2014), depth =410-500 m; (b) Orange= partially serpentinised kimberlite at $370-410 \mathrm{~m}$ and $500-640 \mathrm{~m}$ depth intervals. The upper boundary of kimberlite unit (9) is at $370 \mathrm{~m}$ (according to Kharkiv et al. (1998) and 
Marshintsev et al. (1976)). Other boundaries were constrained during 2003 - 2016 field work. Megascopic and macroscopic photographs of the eastern body kimberlite units are included in Supplementary Data Electronic Appendix 2 (Figs S1 - S16). The area containing the two so-called "epigenetic halite and sedimentary evaporite" units (see Kopylova et al. (2016)) and are indicated in yellow. Host sediments are after Alexseev (2009).

Figure 3. $(a-c)$ Specimens of unserpentinised volcaniclastic kimberlite (VK) cross-cut by a thin dyke $(\sim 10 \mathrm{~cm})$ of coherent kimberlite (CK; sample K24-04A). The inset (top-right) shows a zoom in of this CK dyke cross-cutting VK. Panels (b) and (c) show the sharp boundary between VK and CK. Panel (c) is sample K24-04A and labels (D), (E) and (F) represent the relative positions of groundmass photographs for $(d-f)$ which show the transition in textures from VK to CK. (d) VK, (e) boundary (defined by red-dotted line) between VK and CK, and (f) CK. CK is characterised by more uniform and fine-grained textures and a higher abundance of groundmass oxides (bright phases). Olivine: Ol.

Figure 4. Back-scattered electron (BSE) SEM images of olivine in unserpentinised $(a, b)$ and serpentinised (c, d) VK samples. (a, b) Euhedral to anhedral olivine (Ol) with pronounced zoning and unaltered rims. The groundmass is composed of: euhedral monticellite (Mtc), interstitial alkali-carbonates (dark grey) and calcite (light grey), interstitial chlorides (e.g., halite - Hal); euhedral oxides (e.g., perovskite, magnetite, Cr-spinel, magnesian ulvöspinelmagnetite-MUM) are white. (c, d) Euhedral to anhedral olivine with pronounced zoning and serpentinised rims and fractures. The groundmass is composed of: serpentine (black), calcite (light grey) and euhedral oxides (white).

Figure 5. Histogram of olivine core compositions from serpentinised (dark grey; $n=117$ ) and unserpentinised (light grey; $\mathrm{n}=117$ ) UE kimberlite samples, showing the distribution of forsterite (Fo) mol.\%. 
Figure 6. Back-scattered electron SEM image and X-ray element maps of unserpentinised VK sample UV-K1-15. Olivine (Ol; $\mathrm{Si}, \mathrm{Fe}, \mathrm{Mg}$ maps) is set in a groundmass of S-bearing Na-K-Ca-carbonates (Ca, Na, K, S maps), calcite (highest intensity on Ca-map), sodalite (Al, $\mathrm{Cl}$, Na maps), phlogopite ( $\mathrm{K}, \mathrm{Al}, \mathrm{Mg}$ maps), chlorides (Na, K, $\mathrm{Cl}$ maps), apatite (P maps) and Fe-Ti-oxides (highest intensity on Fe, Ti maps).

Figure 7. Back-scattered electron SEM image and X-ray element maps of serpentinised VK sample K17-04. Olivine (Ol; $\mathrm{Si}, \mathrm{Fe}, \mathrm{Mg}$ maps) is set in a groundmass of serpentine (Srp black; Fe, Mg, Si maps), calcite (Ca map), iowaite (Cl map), phlogopite (K, Al, Mg maps), sulphides (S map), apatite (P map) and Fe-Ti-oxides (Fe, Ti maps).

Figure 8. Relationships in Udachnaya-East whole-rock compositions between $(a-c)$ major element $\left(\mathrm{SiO}_{2}, \mathrm{FeO}, \mathrm{CaO}\right)$ oxides and $\mathrm{MgO}$, (d, e) $\mathrm{Na}_{2} \mathrm{O}$ and $\mathrm{Cl} v s \mathrm{H}_{2} \mathrm{O}$, (f - h) $\mathrm{K}_{2} \mathrm{O}, \mathrm{Na}_{2} \mathrm{O}$ and $\mathrm{S}$ vs $\mathrm{Cl}$. Data points are arranged on a grey scale starting at white (smallest symbols), which represent the least hydrous samples, through to black (largest symbols) which indicate the most hydrous samples. The dashed grey line represents $1 \mathrm{wt} \% \mathrm{H}_{2} \mathrm{O}$. Data for whole-rock compositions are presented in Table 2 and Supplementary Data Electronic Appendix 1 (see also Kamenetsky et al. 2012).

Figure 9. Primitive mantle normalised (after Sun \& McDonough, 1989) incompatible trace element patterns of the UE kimberlite. The coloured lines represent the degree of $\mathrm{H}_{2} \mathrm{O}-$ enrichment in each sample, where dark green represents the most hydrous samples, the yellow represents intermediate, and the red represents the least hydrous. Data given are in Supplementary Data Electronic Appendix 1.

Figure 10. Transmitted light photomicrographs showing different morphologies and abundances of micro-inclusions hosted in olivine from grain separates from serpentinised VK. Inclusions contain blue (c) and purple (d) chlorides. 
Figure 11. Back-scattered electron (BSE) SEM images of multiphase secondary melt inclusions in olivine (Ol) from serpentinised $(a, b) \mathrm{VK}$ and $(\mathrm{c}, \mathrm{d}) \mathrm{AC} .(\mathrm{a}, \mathrm{b})$ Trails of secondary inclusions composed of halite (Hal), tetraferriphlogopite (Tet), sylvite (Syl), phlogopite (Phl), magnetite (Mag), djerfisherite (Dj) and Fe-sulphides (Fe-S). (c, d) Large multiphase inclusions in olivine composed of tetraferriphlogopite, sylvite, nyerereite (Ny), magnetite, monticellite (Mtc), Ba-carbonate (Ba-Cb), humite $(\mathrm{Hu})$, alkali $(\mathrm{Na}, \mathrm{K})$ carbonate (Alk-Cb), magnesian ulvöspinel-magnetite (MUM) and natrite (Nat). Inclusions are commonly surrounded by patchy zoning of olivine $(\mathrm{Ol}(\mathrm{Z}))$ which is characterised by an elevated Fo content.

Figure 12. Back-scattered electron SEM image and X-ray elemental maps of a secondary multiphase melt inclusion in olivine $(\mathrm{Ol})$ from serpentinised AC. Detected minerals include: halite (Hal), perovskite (Pvk), calcite (Cc), sylvite (Syl), magnesian ulvöspinel-magnetite (MUM) and unidentified Na-K-S \pm Cl-bearing phases. The red/yellow line indicates the boundary of the inclusion.

Figure 13. Back-scattered electron (BSE) SEM images of multiphase inclusions in olivine (Ol) from unserpentinised VK. Multiphase inclusions in olivine are composed of halite (Hal), sylvite (Syl), magnetite (Mag), magnesian ulvöspinel-magnetite (MUM), phlogopite (Phl), tetraferriphlogopite (Tet), nyerereite (Ny) and unidentified $\mathrm{Ca}-\mathrm{Na} / \mathrm{K}-\mathrm{S}-$ bearing phases.

Figure 14. Back-scattered electron (BSE; $a-d$ and $h$ ) and secondary electron (SE; e - g) SEM images of primary multiphase melt inclusions in $(a, b)$ monticellite from serpentinised VK, (c) monticellite from unserpentinised VK, (d) Cr-spinel (Cr-Spl) in unserpentinised VK, (e, f) magnesian ulvöspinel-magnetite (MUM) and (g) perovskite (Pvk) in unserpentinised $\mathrm{CK}$, and (h) groundmass calcite $(\mathrm{Cc})$ in serpentinised VK. Detected phases within inclusions include: apatite, (Ap), perovskite, alkali $(\mathrm{Na}, \mathrm{K})$ chlorides $(\mathrm{Alk}-\mathrm{Cl})$, alkali $(\mathrm{Na}, \mathrm{K})$ sulphur- 
bearing phases (Alk-S), phlogopite (Phl), alkali (Na, K) carbonate, halite (Hal), djerfisherite (Djer), dolomite (Dol), magnetite (Mag), Fe-Mg-oxide (Fe-Mg-ox) and unidentified Fe-MgP-K-bearing phases. MUM-spinel also contains monocrystalline inclusions of olivine (Ol).

Figure 15. Summary of the ideas presented by Kopylova et al. (2013, 2016; MK'13, MK'16) and Kostrovitsky et al. (2013; SK'13) on the geological position and origin of the low- $\mathrm{H}_{2} \mathrm{O}$, alkali-chlorine-sulphur enriched unserpentinised Udachnaya-East kimberlite. VK: volcaniclastic kimberlite, PK: pyroclastic kimberlite, CK: coherent kimberlite.

Figure 16. Schematic diagram of the entrapment of secondary olivine-hosted inclusions. Stage (1): Fracturing of olivine during magma ascent. Stage (2): Penetration of kimberlite melt into olivine fractures during transport and, or, upon emplacement. (3) Healing and trapping of inclusions in olivine and crystallisation of olivine overgrowths around preexisting grains. 


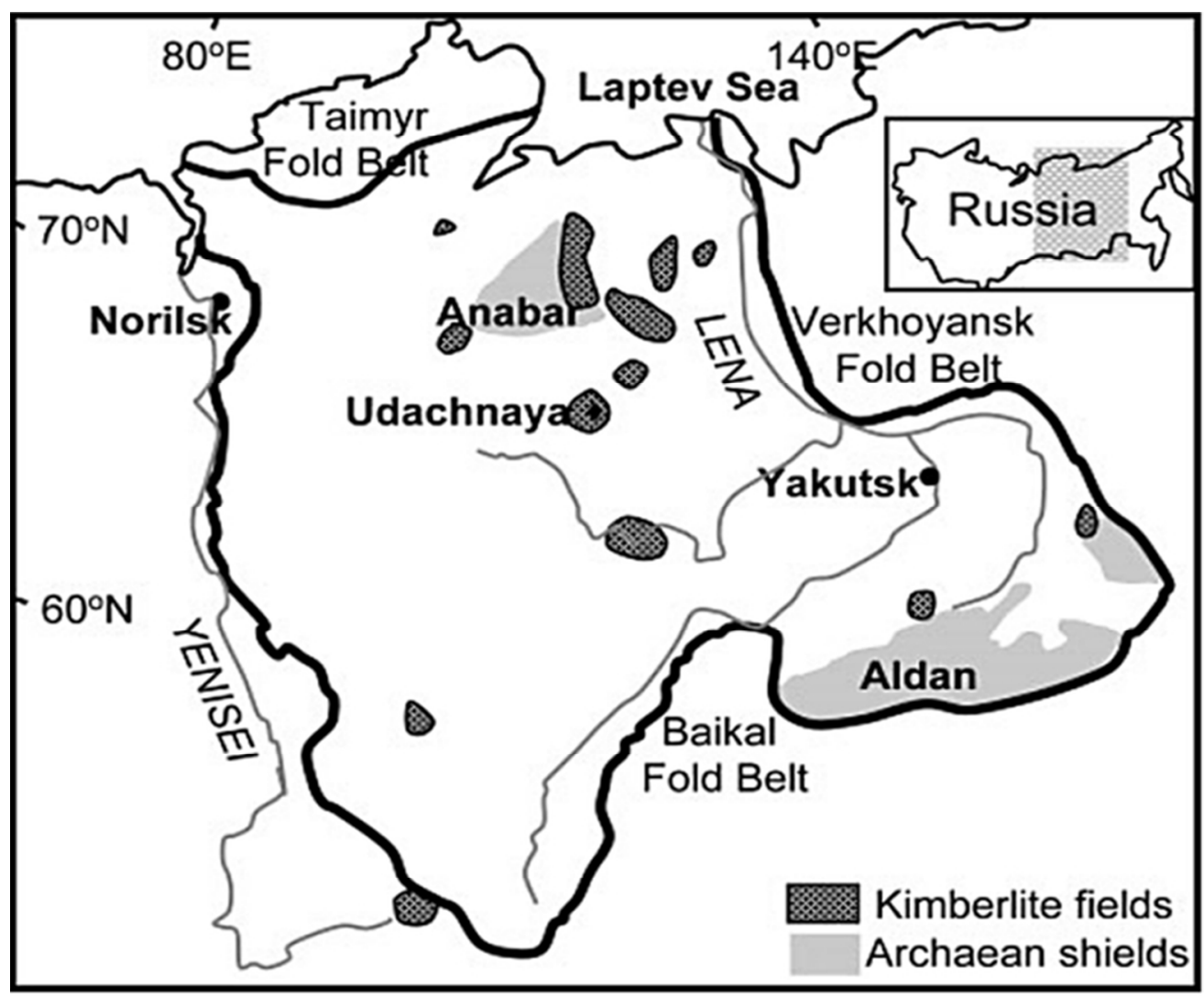

Figure 1. Map of the Siberian Platform showing the location of the Udachnaya kimberlite and other kimberlite fields after Pearson et al. (1995) and Kamenetsky et al. (2008).

$65 \times 54 \mathrm{~mm}(300 \times 300 \mathrm{DPI})$ 


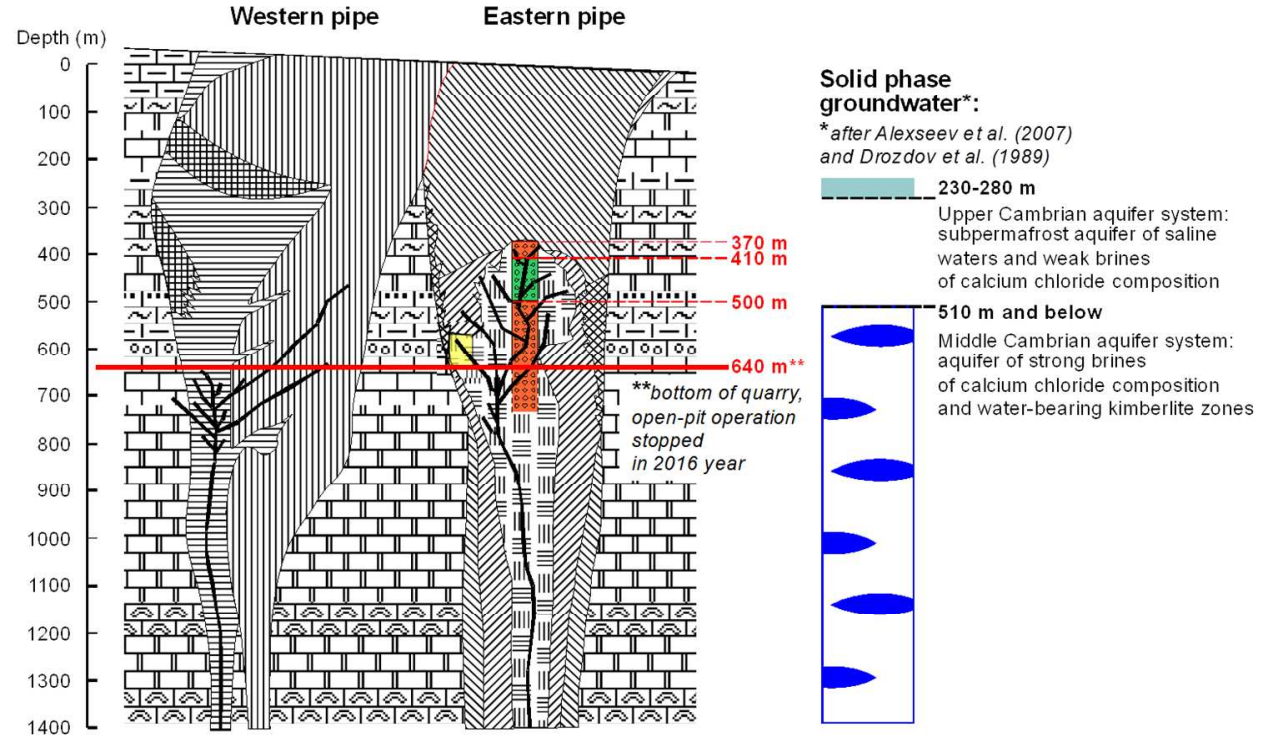

Kimberlite rocks:

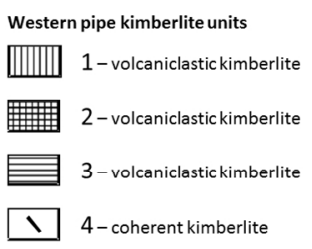

Eastern pipe kimberlite units

MU. 5-volcaniclastic kimberlite

6 -volcaniclastickimberlite

7-volcaniclastic kimberlite

EIIII 8 -volcaniclastic kimberlite

$\because \cdots: 99$ - volcaniclastic unserpentinised kimberlite

$\because \cdots 99 \mathrm{~b}$-volcaniclastic partially serpentinised kimberlite

10 -coherent kimberlite
Host sediments:

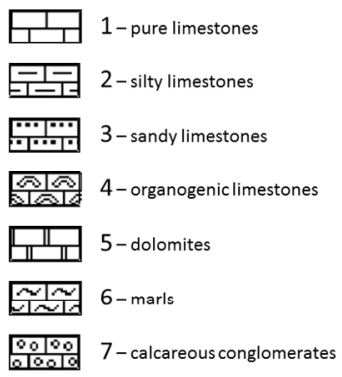

Figure 2. Geological cross-section of the Udachnaya kimberlite pipes (edited after Golovin et al. (2017)). Units $1-4$ = western body, which contains volcaniclastic kimberlite (units $1-3$, which have well defined boundaries) and veins of coherent kimberlite (4). Units $5-10=$ eastern body, which consists of volcaniclastic kimberlite (units $5-9$, which have well defined boundaries) and veins of coherent kimberlites (10). Volcaniclastic kimberlite unit 9 can be divided into two types (a) and (b). Although the textural and structural characteristics for these types are identical, there are various changes in groundmass mineralogy that take place at different depths. Volcaniclastic kimberlite unit 9: (a) Green = unserpentinised 'fresh' kimberlite (see Kamenetsky et al., 2012, 2014), depth $=410-500 \mathrm{~m}$; (b) Orange = partially serpentinised kimberlites at $370-410 \mathrm{~m}$ and $500-640 \mathrm{~m}$ depth intervals. The upper boundary for kimberlite unit (9) is at $370 \mathrm{~m}$ (according to Kharkiv et al. (1998) and Marshintsev et al. (1976)). Other boundaries were constrained during 2003 - 2016 field work in the quarry. Megascopic and macroscopic photos of the eastern body kimberlite units are also present in Electronic Appendix 2 (Fig. S1 - S16). The area containing the two so-called "epigenetic halite and sedimentary evaporites" units (see Kopylova et al. (2016)) and are indicated in yellow. Host sediments are presented after Alexseev (2009). 
$143 \times 171 \mathrm{~mm}(284 \times 284 \mathrm{DPI})$

Downloaded from https://academic.oup.com/petrology/advance-article-abstract/doi/10.1093/petrology/egy068/5050908 by guest

by guest 201 


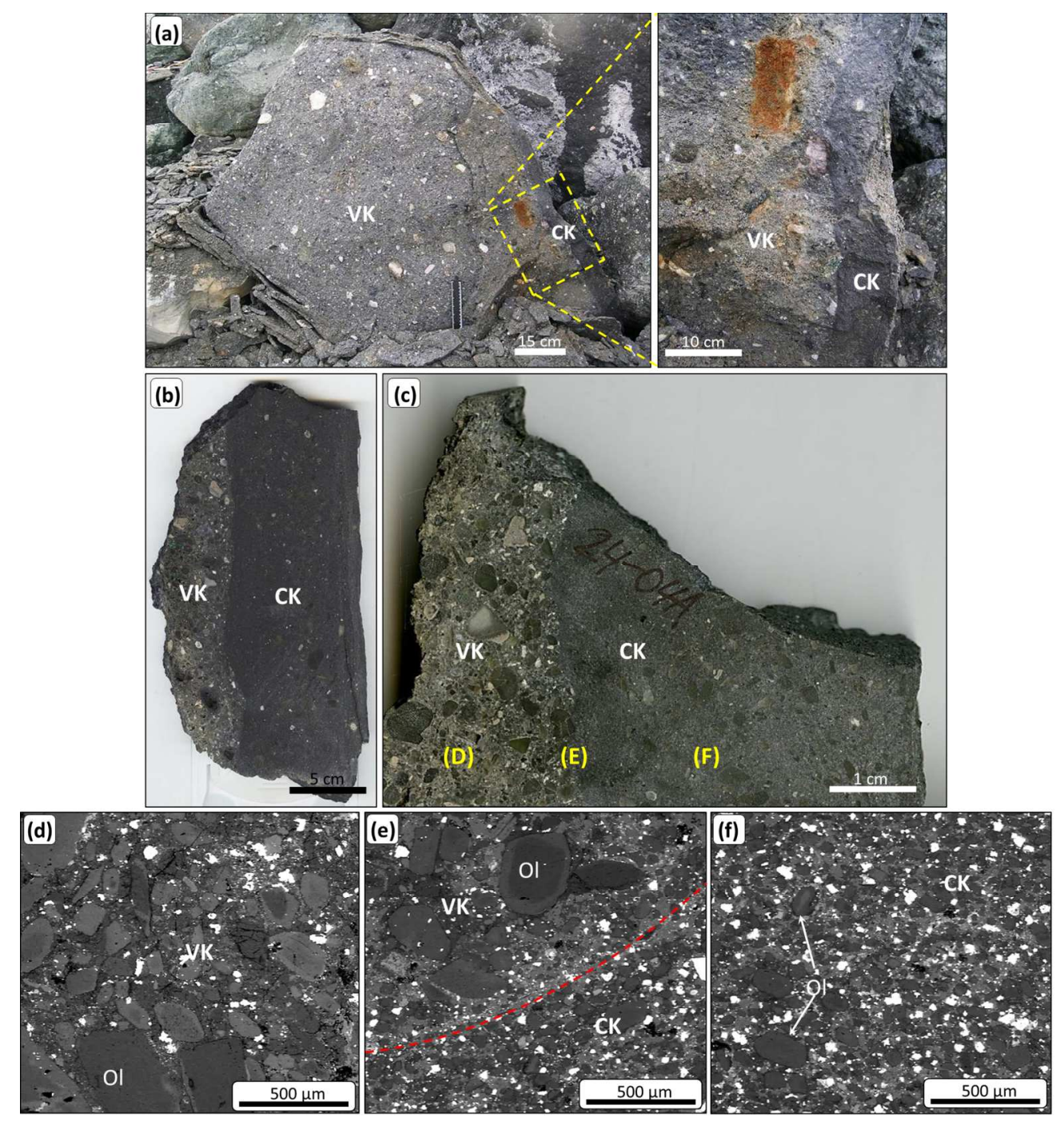

Figure 3. $(\mathrm{a}-\mathrm{c})$ Specimens of unserpentinised volcaniclastic kimberlite (VK) cross-cut by a thin dyke $(\sim 10$ $\mathrm{cm}$ ) of coherent kimberlite (CK; sample K24-04A). The inset (top-right) shows a zoom in of this CK dyke cross-cutting VK. Panels (b) and (c) show the sharp boundary between VK and CK. Panel (c) is sample K2404A and labels (D), (E) and (F) represent the relative positions of groundmass photographs for $(d-f)$ which show the transition in textures from VK to CK. (d) VK, (e) boundary (defined by red-dotted line) between VK and $\mathrm{CK}$, and ( $\mathrm{f}$ ) $\mathrm{CK}$. The $\mathrm{CK}$ is characterised by more uniform and fine-grain textures and a higher abundance of groundmass oxides (bright phases). Olivine: Ol.

$173 \times 184 \mathrm{~mm}(300 \times 300$ DPI $)$ 

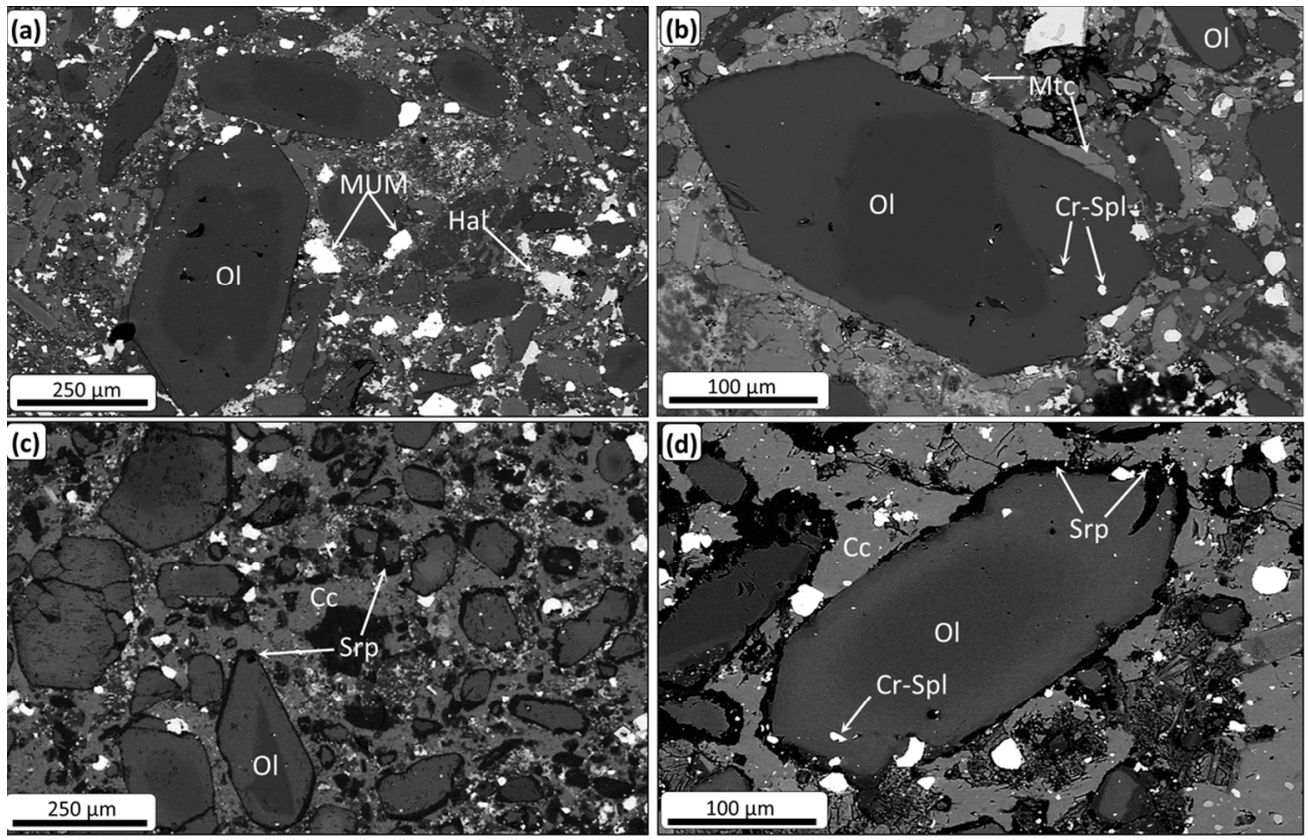

Figure 4. Back-scattered electron (BSE) SEM images of olivine in unserpentinised (a, b) and serpentinised (c, d) VK samples. (a, b) Euhedral-to-anhedral shaped olivine (OI) with pronounced zoning and unaltered rims. The groundmass is composed of: euhedral-shaped monticellite (Mtc), interstitial alkali-carbonates

(dark grey) and calcite (light grey), interstitial chlorides (e.g., halite - Hal) euhedral oxides (e.g., perovskite, magnetite, Cr-spinel, magnesian ulvöspinel-magnetite - MUM) are white. (c, d) Euhedral-toanhedral shaped olivine with pronounced zoning and serpentinised rims and fractures. The groundmass is composed of: serpentine (black), calcite (light grey) and euhedral oxides (white).

$104 \times 67 \mathrm{~mm}(300 \times 300 \mathrm{DPI})$ 


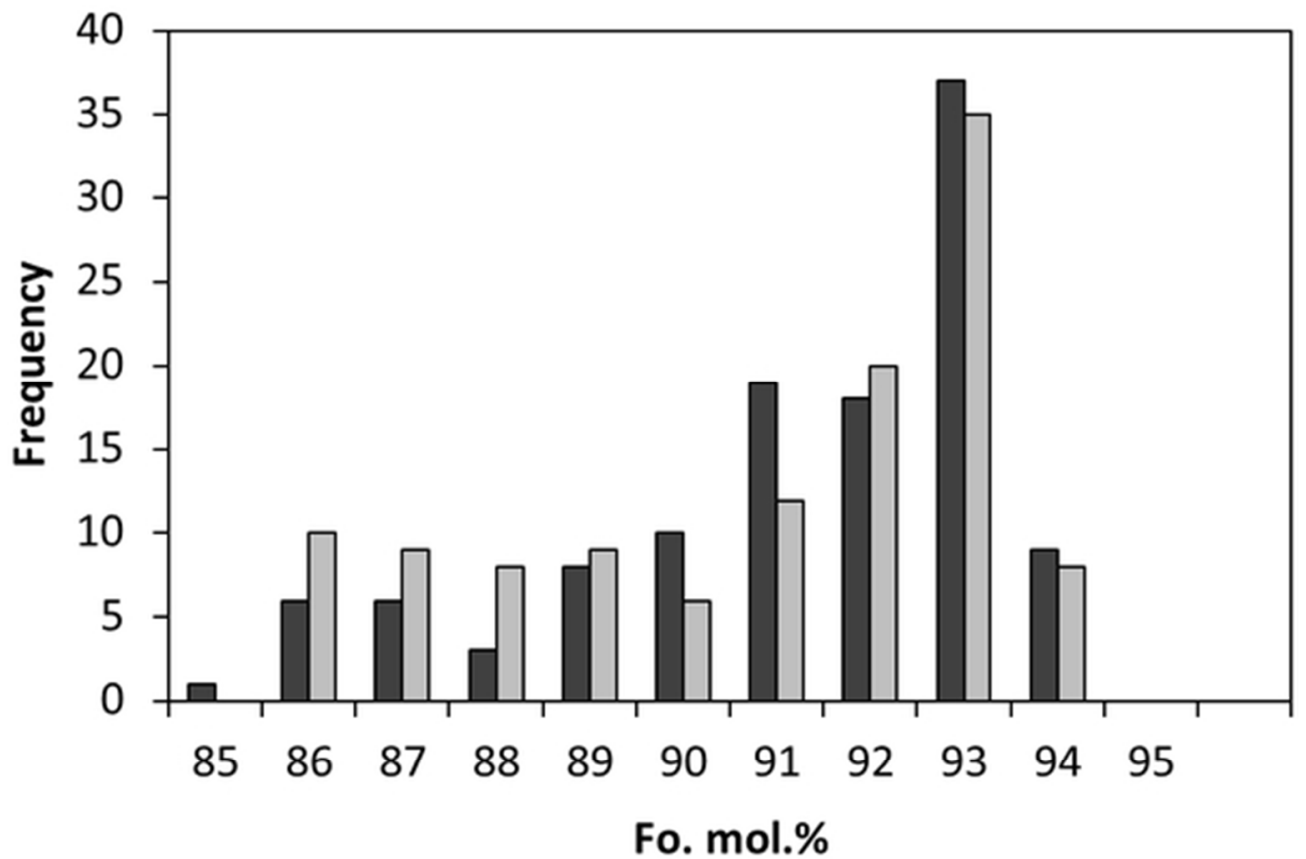

Figure 5. Histogram of olivine core compositions from serpentinised (dark grey; $n=117$ ) and unserpentinised (light grey; $n=117$ ) UE kimberlite samples showing the distribution of forsterite (Fo) mol.\%.

$$
51 \times 34 \mathrm{~mm}(300 \times 300 \mathrm{DPI})
$$



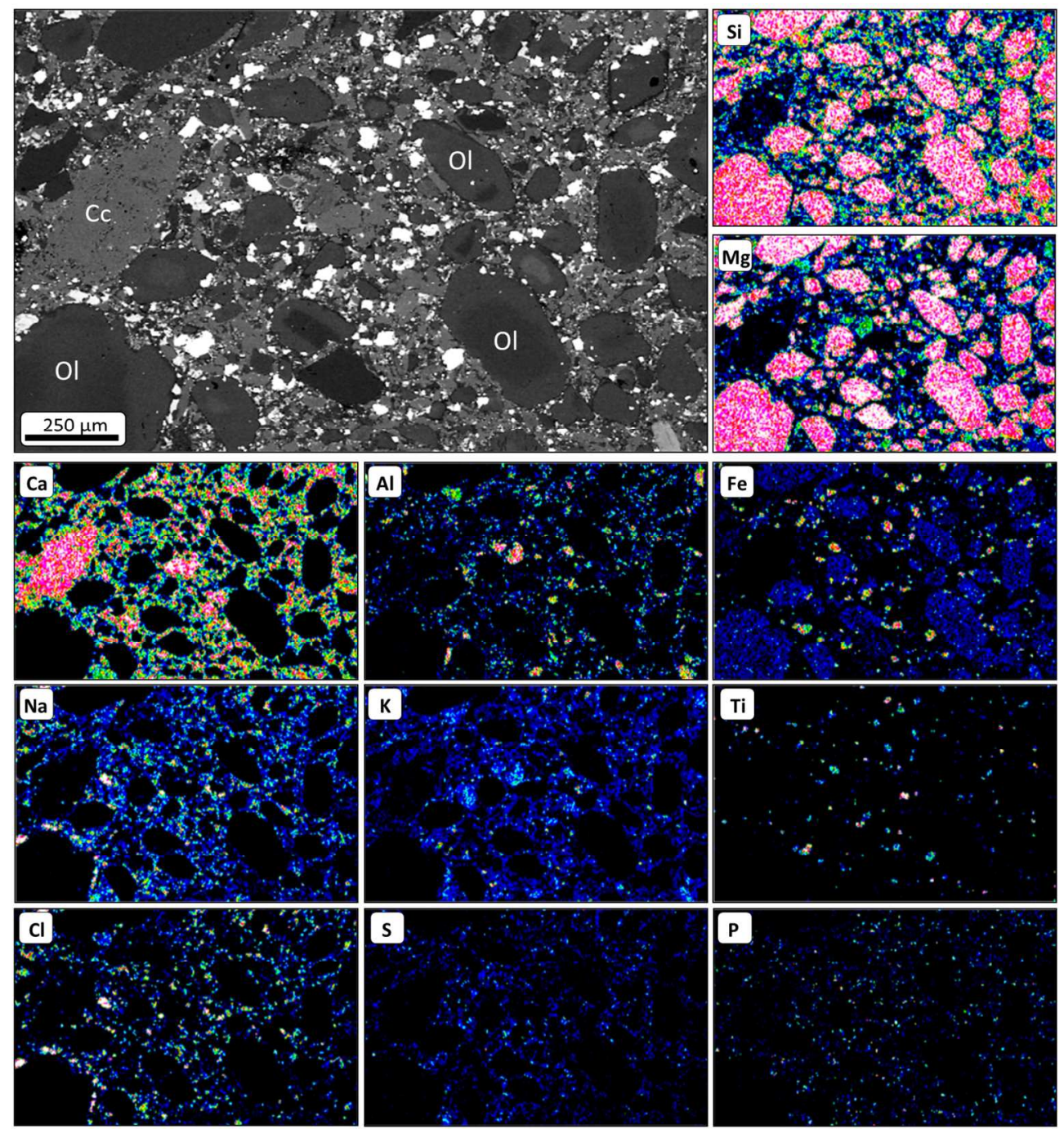

$\min$

$\max$

Figure 6. Back-scattered electron SEM image and X-ray elemental maps of unserpentinised VK sample UV$\mathrm{K} 1-15$. Olivine (Ol; $\mathrm{Si}, \mathrm{Fe}, \mathrm{Mg}$ maps) is set in a groundmass of $\mathrm{S}$-bearing $\mathrm{Na}-\mathrm{K}-\mathrm{Ca}$-carbonates (Ca, $\mathrm{Na}, \mathrm{K}, \mathrm{S}$ maps), calcite (highest intensity on Ca-map), sodalite ( $\mathrm{Al}, \mathrm{Cl}, \mathrm{Na}$ maps), phlogopite ( $\mathrm{K}, \mathrm{Al}, \mathrm{Mg}$ maps), chlorides ( $\mathrm{Na}, \mathrm{K}, \mathrm{Cl}$ maps), apatite ( $\mathrm{P}$ maps) and Fe-Ti-oxides (highest intensity on Fe, Ti maps).

$155 \times 170 \mathrm{~mm}(300 \times 300 \mathrm{DPI})$ 

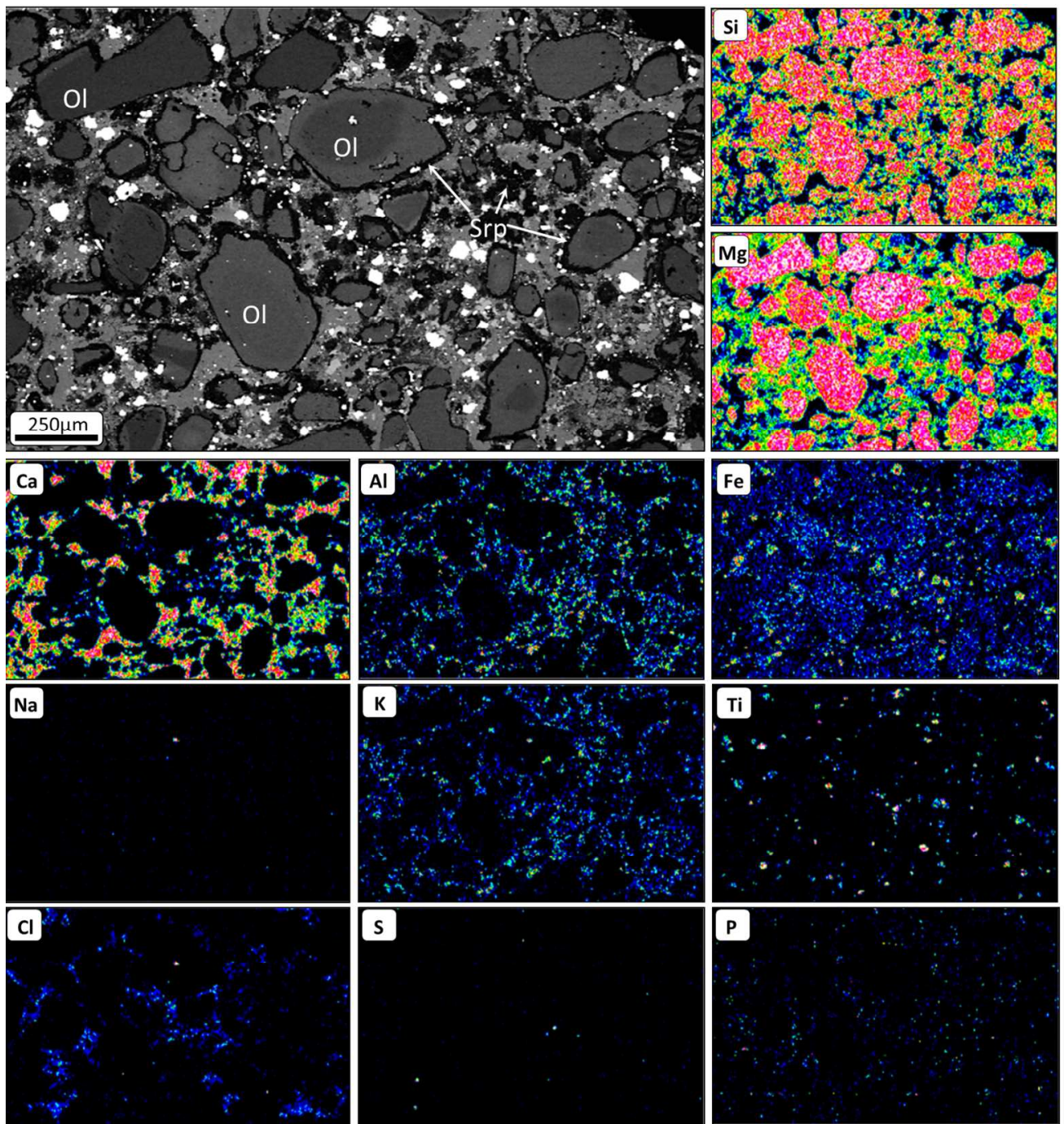

$\min$

$\max$

Figure 7. Back-scattered electron SEM image and X-ray elemental map of serpentinised VK sample K17-04. Olivine (Ol; Si, Fe, Mg maps) is set in a groundmass of serpentine (Srp - black; Fe, Mg, Si maps), calcite (Ca map), iowaite ( $\mathrm{Cl}$ map), phlogopite ( $\mathrm{K}, \mathrm{Al}, \mathrm{Mg}$ maps), sulphides ( $\mathrm{S}$ map), apatite ( $\mathrm{P}$ map) and $\mathrm{Fe}-\mathrm{Ti}-$ oxides (Fe, Ti maps).

$154 \times 170 \mathrm{~mm}(300 \times 300 \mathrm{DPI})$ 

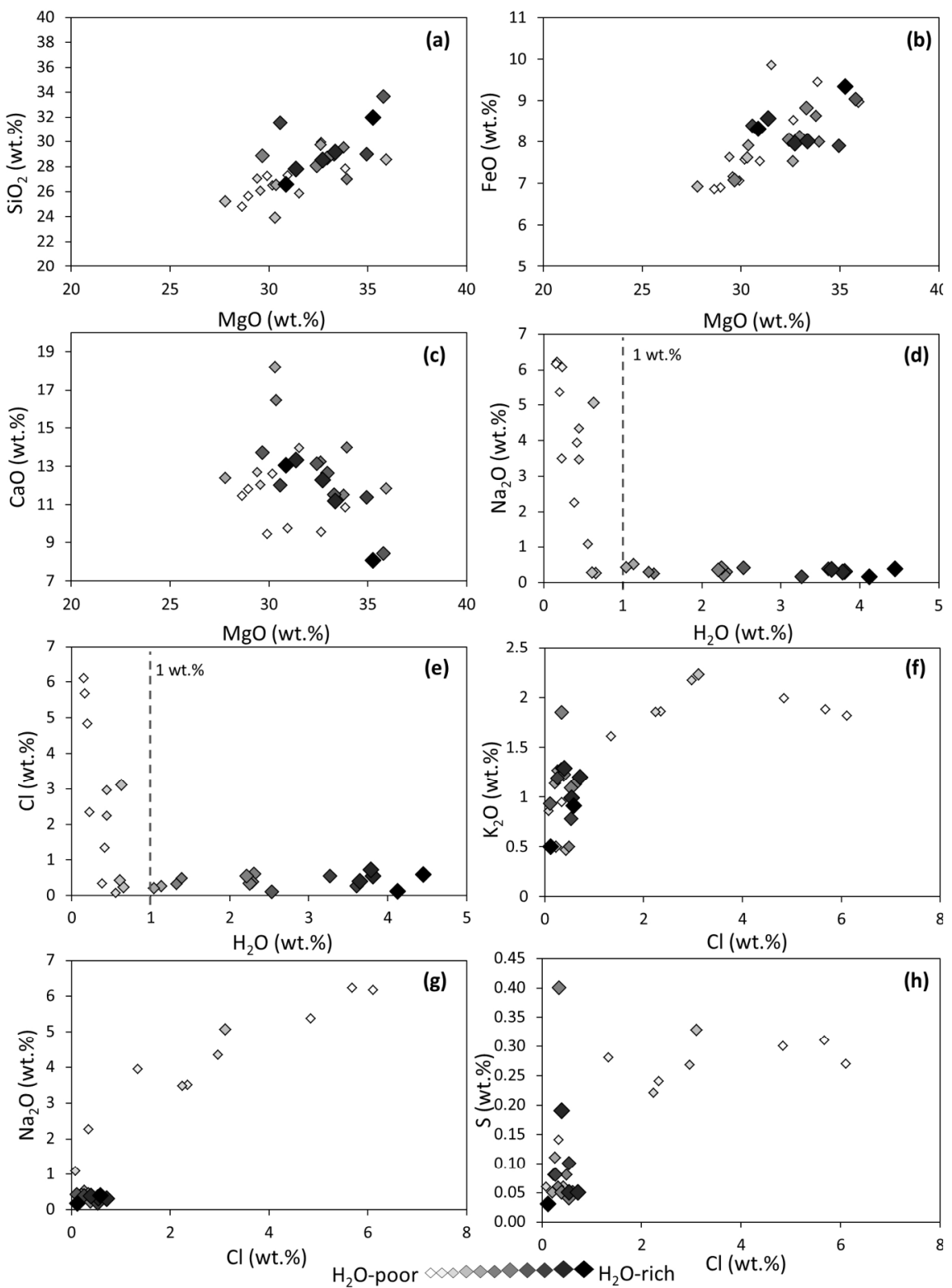

Figure 8. Relationships in Udachnaya-East whole-rock compositions between (a - c) major element ( $\mathrm{SiO}$, $\mathrm{FeO}, \mathrm{CaO}$ ) oxides and $\mathrm{MgO},(\mathrm{d}, \mathrm{e}) \mathrm{Na} 2 \mathrm{O}$ and $\mathrm{Cl}$ vs. $\mathrm{H} 2 \mathrm{O}$, (f - h) K2O, $\mathrm{Na} 2 \mathrm{O}$ and $\mathrm{S}$ vs. $\mathrm{Cl}$. Data points are arranged on a grey scale starting at white (smallest symbols), which represent the least hydrous samples, through to black (largest symbols) which indicate the most hydrous samples. The dotted grey line represents $1 \mathrm{wt}$ \% H2O. Data for whole-rock compositions is presented in Table 2 and Electronic Appendix 1 (see also Kamenetsky et al. 2012).

$203 \times 276 \mathrm{~mm}(300 \times 300$ DPI $)$ 


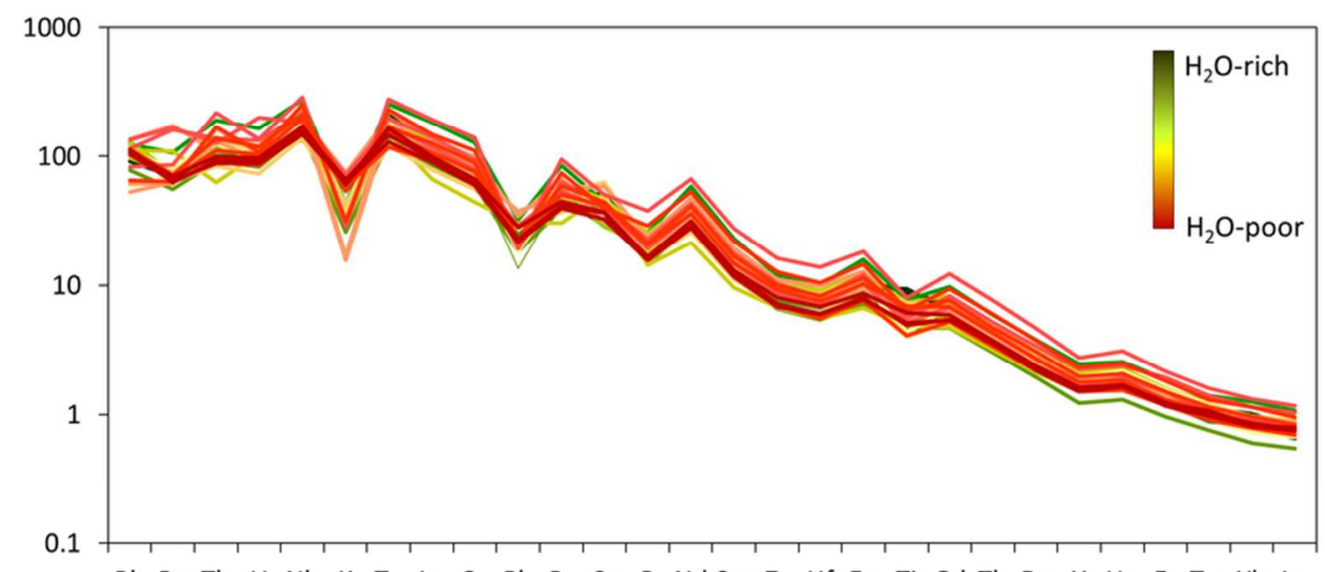

$\mathrm{Rb}$ Ba Th U Nb K Ta La Ce Pb Pr Sr P Nd Sm Zr Hf Eu Ti Gd Tb Dy Y Ho Er Tm Yb Lu

Figure 9. Primitive mantle normalised (after Sun and McDonough, 1989) incompatible trace element patterns of the UE kimberlite. The coloured lines represent the degree of $\mathrm{H} 2 \mathrm{O}$-enrichment in each sample, where dark green represents the most hydrous samples, the yellow represents intermediate, and the red represents the least hydrous. Data values are in Electronic Appendix 1.

$72 \times 32 \mathrm{~mm}(300 \times 300 \mathrm{DPI})$ 

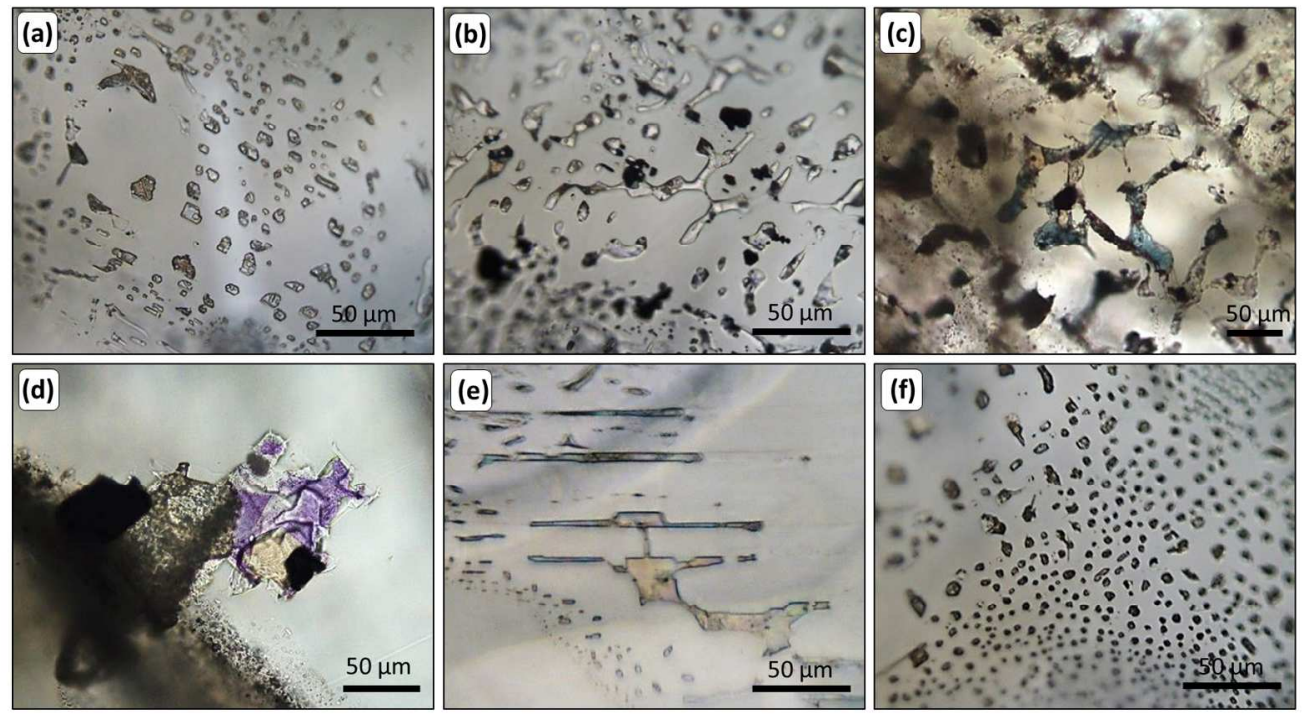

Figure 10. Optical transmitted light photographs showing different morphologies and abundances of microinclusions hosted in olivine from grain separates from serpentinised VK. Inclusions contain blue (c) and purple (d) chlorides.

$159 \times 87 \mathrm{~mm}(284 \times 284 \mathrm{DPI})$ 

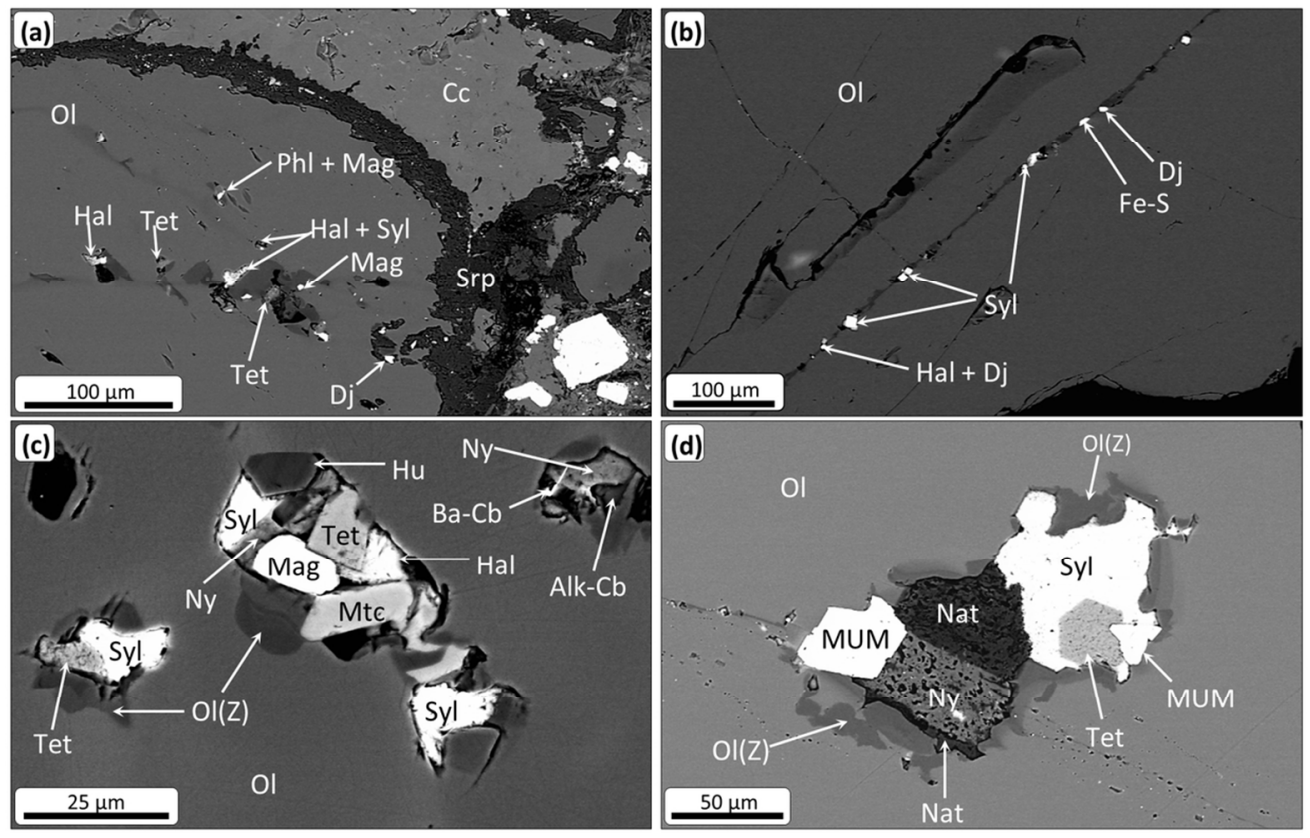

Figure 11. Back-scattered electron (BSE) SEM images of multiphase secondary melt inclusions in olivine (OI) from serpentinised (a, b) VK and (c, d) AC. (a, b) Trails of secondary inclusions composed of halite (Hal), tetraferriphlogopite (Tet), sylvite (Syl), phlogopite (Phl), magnetite (Mag), djerfisherite (Dj) and Fesulphides (Fe-S). (c, d) Large multiphase inclusions in olivine composed of tetraferriphlogopite, sylvite, nyerereite (Ny), magnetite, monticellite (Mtc), Ba-carbonate (Ba-Cb), humite (Hu), alkali (Na, K) carbonate (Alk-Cb), magnesian ulvöspinel-magnetite (MUM) and natrite (Nat). Inclusions are commonly surrounded by patchy zoning of olivine $(\mathrm{OI}(Z))$ which is characterised by elevated Fo-content.

$104 \times 66 \mathrm{~mm}(300 \times 300$ DPI $)$ 

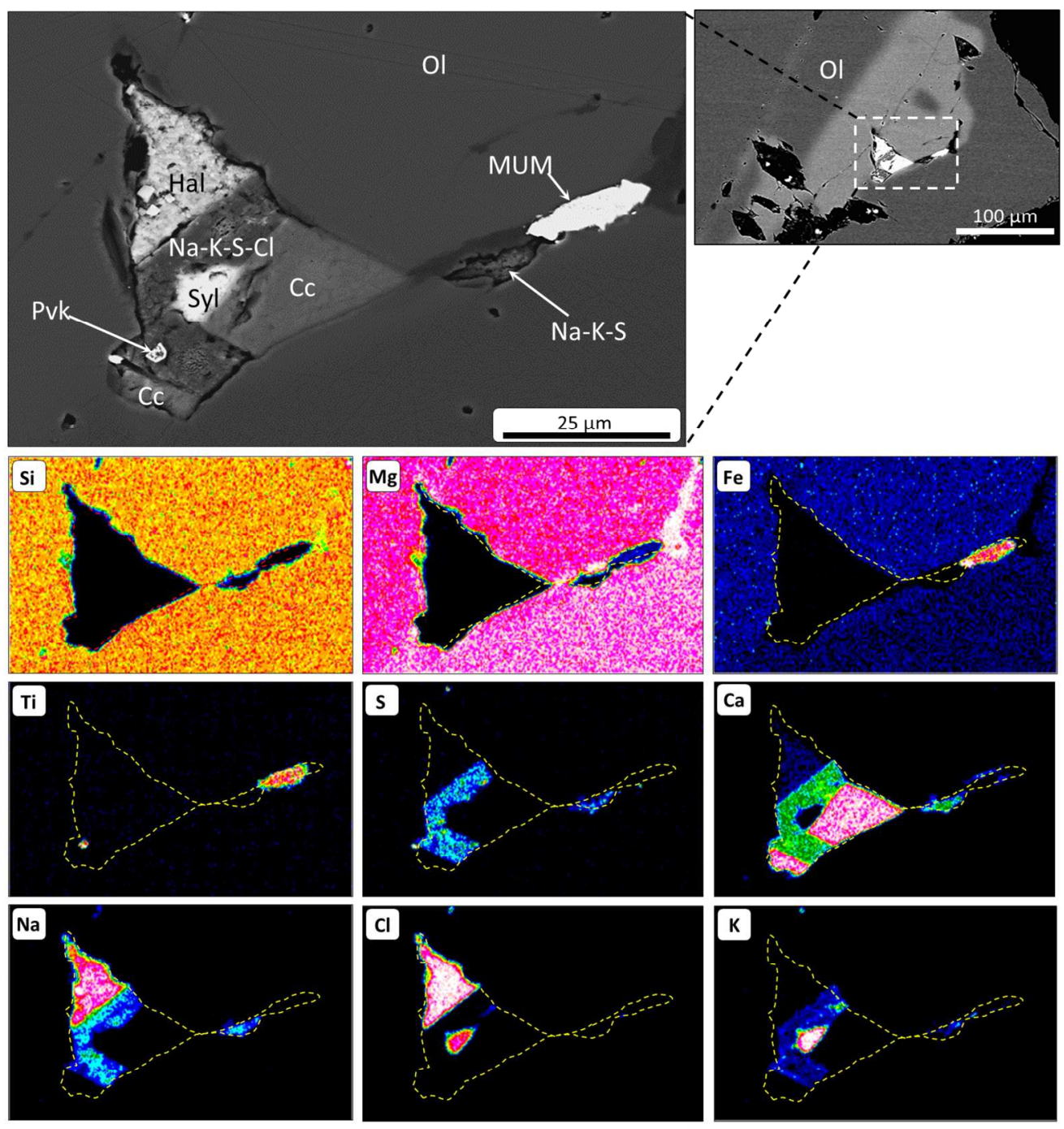

$\min$

$\max$

Figure 12. Back-scattered electron SEM image and X-ray elemental map of a secondary multiphase melt inclusion in olivine (OI) from serpentinised AC. Detected minerals include: halite (Hal), perovskite (Pvk), calcite (Cc), sylvite (Syl), magnesian ulvöspinel-magnetite (MUM) and unidentified $\mathrm{Na}-\mathrm{K}-\mathrm{S} \pm \mathrm{Cl}$-bearing phases. The red/yellow line represents the boundary of the inclusion.

$156 \times 173 \mathrm{~mm}(300 \times 300 \mathrm{DPI})$ 

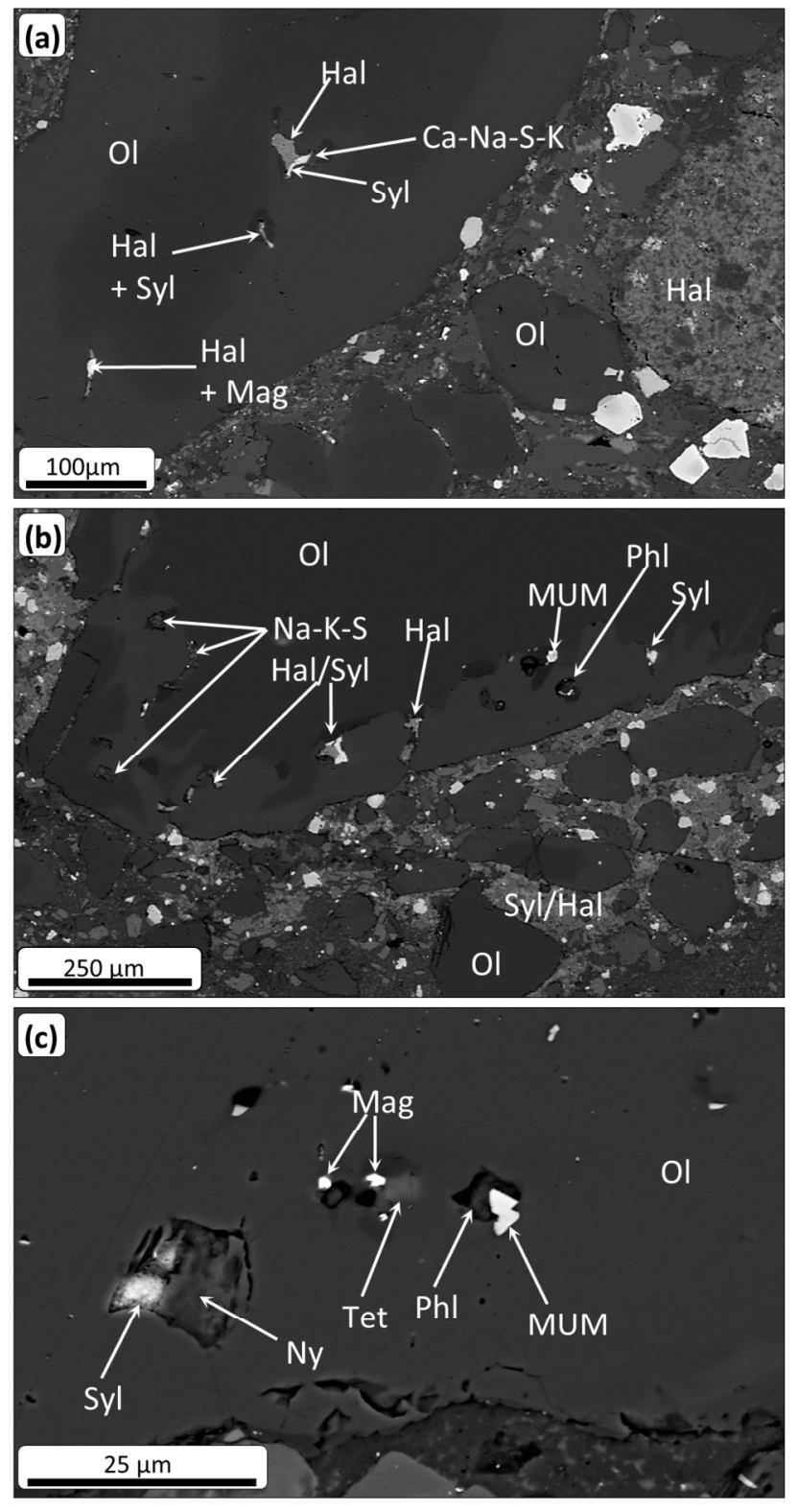

Figure 13. Back-scattered electron (BSE) SEM images of multiphase inclusions in olivine (OI) from unserpentinised VK. Multiphase inclusions in olivine are composed of halite (Hal), sylvite (Syl), magnetite (Mag), magnesian ulvöspinel-magnetite (MUM), phlogopite (Phl), tetraferriphlogopite (Tet), nyerereite (Ny) and unidentified $\mathrm{Ca}-\mathrm{Na} / \mathrm{K}-\mathrm{S}$-bearing phases.

$$
159 \times 305 \mathrm{~mm}(300 \times 300 \mathrm{DPI})
$$



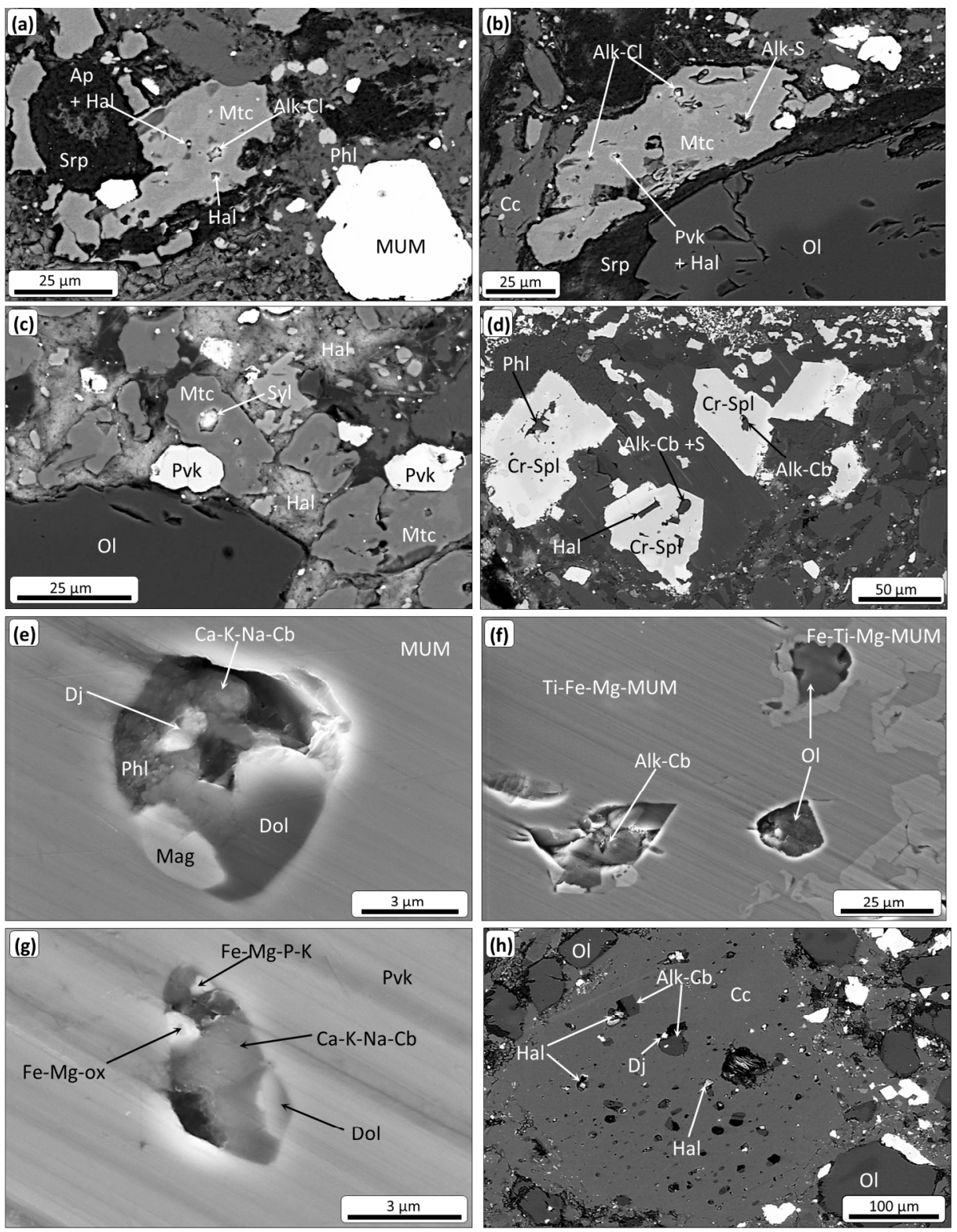

Figure 14. Back-scattered electron (BSE; $a-d$ and $h$ ) and secondary electron (SE; e - g) SEM images of primary multiphase melt inclusions in $(a, b)$ monticellite from serpentinised $V K,(c)$ monticellite from unserpentinised VK, (d) Cr-spinel (Cr-Spl) in unserpentinised VK, (e, f) magnesian ulvöspinel-magnetite (MUM) and ( $g$ ) perovskite (Pvk) in unserpentinised $\mathrm{CK}$, and $(\mathrm{h})$ groundmass calcite $(\mathrm{Cc})$ in serpentinised VK. Detected phases within inclusions include: apatite, (Ap), perovskite, alkali ( $\mathrm{Na}, \mathrm{K})$ chlorides (Alk-Cl), alkali $(\mathrm{Na}, \mathrm{K})$ sulphur-bearing phases (Alk-S), phlogopite $(\mathrm{Phl})$, alkali $(\mathrm{Na}, \mathrm{K})$ carbonate, halite (Hal), djerfisherite (Djer), dolomite (Dol), magnetite (Mag), Fe-Mg-oxide (Fe-Mg-ox) and unidentified Fe-Mg-P-K-bearing phases. MUM-spinel also contains monocrystalline inclusions of olivine $(\mathrm{Ol})$. 


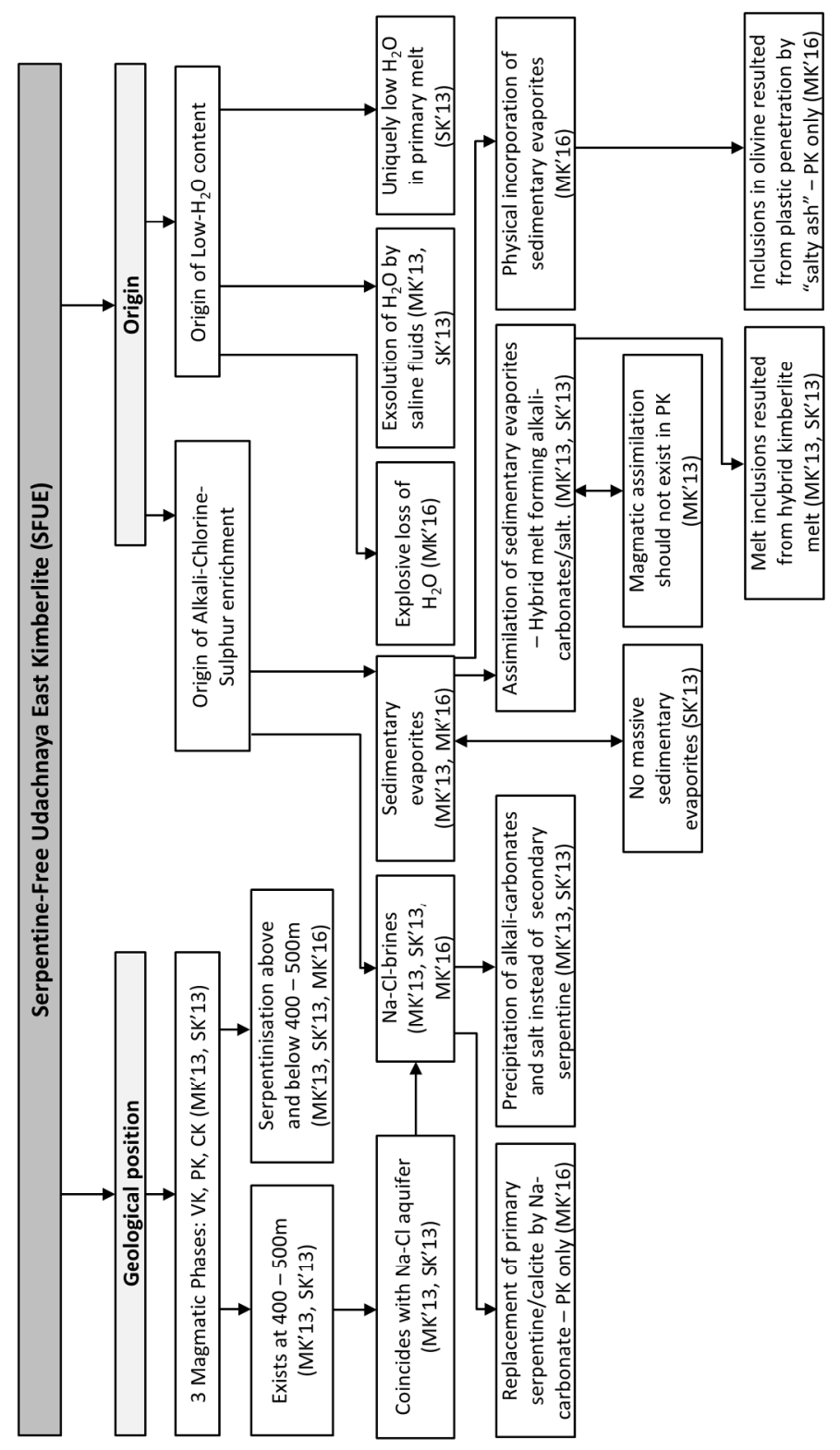

Figure 15. Summary of ideas presented by Kopylova et al. (2013, 2016; MK'13, MK'16) and Kostrovitsky et al. (2013; SK'13) on the geological position and origin of the low-H2O, alkali-chlorine-sulphur enriched kimberlite unserpentinised Udachnaya-East kimberlite. VK: volcaniclastic kimberlite, PK: pyroclastic kimberlite, CK: coherent kimberlite.

$138 \times 238 \mathrm{~mm}(284 \times 284 \mathrm{DPI})$ 


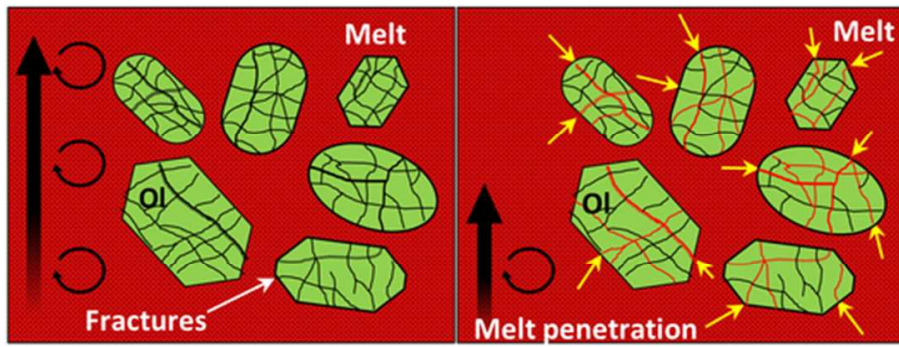

Stage 1: Mechanical (Fracturing then rounding) rounding and fracturing of olivine $(\mathrm{Ol}$ ) as a result of dynamic magmatic ascent and decompression.
Stage 2: Penetration of kimberlite melt into fractures in olivine. This may happen during transport and/or upon emplacement.

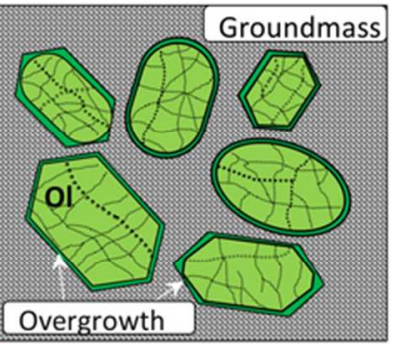

Stage 3: Healing and trapping of secondary inclusions (dotted) in olivine. In-situ crystallisation of olivine overgrowths (dark green) and groundmass (grey).

Figure 16. Schematic diagram of the entrapment of secondary olivine-hosted inclusions. Stage (1):

Fracturing of olivine during magmatic ascent. Stage (2): Penetration of kimberlite melt into olivine fractures during transport and/or upon emplacement. (3) Healing and trapping of inclusions in olivine and crystallisation of olivine overgrowths around pre-existing grains.

$64 \times 25 \mathrm{~mm}(300 \times 300 \mathrm{DPI})$ 
TABLE 1: Summary of mineralogical similarities and differences for serpentinised and unserpentinised Udachnaya-East kimberlite samples.

\begin{tabular}{|c|c|c|c|c|c|}
\hline Sample & Depth of Sampling & Lithology & Mineralogical Similarities & Key Unique Minerals & Approximate Mineral Abundances (\%) \\
\hline \multicolumn{6}{|c|}{ Serpentinised Samples } \\
\hline K16/05 & $500-520$ & $A C$ & \multirow{12}{*}{$\begin{array}{l}\text { Olivine, Monticellite, Phlogopite, } \\
\text { Calcite, Perovskite, Ilmenite } \\
\text { (macrocrysts), Mg-Ti-Magnetite, } \\
\text { Magnesian Ulvöspinel-Magnetite } \\
\text { (MUM), Pleonaste, Cr-Spinel, Apatite, } \\
\text { Fe-Ni-Sulphides, Djerfisherite }\end{array}$} & \multirow{6}{*}{ Serpentine, lowaite } & \multirow{6}{*}{$\begin{array}{l}\text { Olivine: } 40-50 \text {, Calcite: } 15-25 \text {, Serpentine: } \\
\text { 10-25, Spinel + Perovskite: } 5-15 \text {, } \\
\text { Monticellite: } 3-4 \text {, lowaite: } 3-4 \text {, Phlogopite: } \\
\text { 2-4, Ilmenite: } 1-2 \text {, Apatite: } \leq 1 \text {, Sulphides: } \leq 1\end{array}$} \\
\hline K-U & $400-420$ & VK & & & \\
\hline K17/04 & $480-500$ & VK & & & \\
\hline K28/05 & $500-520$ & $A C$ & & & \\
\hline K25/04 & $480-500$ & VK & & & \\
\hline K20-05 & $500-520$ & VK & & & \\
\hline \multicolumn{2}{|c|}{ Unserpentinised Samples } & & & & Olivine: 50-60, Calcite: 10-15, Alkali- \\
\hline K24/04A & $480-500$ & $\mathrm{CK}$ & & & Carbonates: $10-15$, Spinel + Perovskite: $5-$ \\
\hline K2-03 & $440-480$ & VK & & Halite, Sylvite, Alkali ( $\mathrm{Na}, \mathrm{K}$ ) & 15, Chlorides: $4-6$, Sodalite: $3-5$ \\
\hline K24/04B & $480-500$ & VK & & Carbonates (including $\mathrm{SO}_{4}{ }^{2-}$ & Monticellite: $3-4$, Phlogopite: $2-4$, Ilmenite: \\
\hline UV-K1-15 & $440-480$ & VK & & bearing), Sodalite & 1-2, Apatite: $\leq 1$, Sulphides: $\leq 1$ \\
\hline UV-K1-05 & $440-480$ & VK & & & \\
\hline
\end{tabular}

Depth of sampling (in meters) reflect most likely position in the mining pit for most samples as they were taken from stockpiles.

$\mathrm{CK}=$ coherent kimberlite; $\mathrm{VK}=$ volcaniclastic kimberlite; $\mathrm{AC}=$ Autolithic clasts of kimberlite (or autoliths) - hosted in VK. 
TABLE 2: Representative whole-rock major element compositions of the Udachnaya-East kimberlite. Analyses are ordered from highest $\mathrm{H}_{2} \mathrm{O}$ content through to lowest.

\begin{tabular}{|c|c|c|c|c|c|c|c|c|c|c|c|c|c|c|c|c|}
\hline Sample & $\mathrm{SiO}_{2}$ & $\mathrm{TiO}_{2}$ & $\mathrm{Al}_{2} \mathrm{O}_{3}$ & $\mathrm{FeO}$ & $\mathrm{MnO}$ & MgO & $\mathrm{CaO}$ & $\mathrm{Na}_{2} \mathrm{O}$ & K2O & $\mathbf{P}_{\mathbf{2}} \mathbf{O}_{5}$ & $\mathrm{Cl}$ & LOI & Total & $S$ & $\mathrm{CO}_{2}$ & $\mathrm{H}_{2} \mathrm{O}$ \\
\hline K16/05 & 26.58 & 1.81 & 1.72 & 8.32 & 0.13 & 30.87 & 13.06 & 0.39 & 0.91 & 0.48 & 0.59 & 13.74 & 98.59 & $\mathrm{n} / \mathrm{a}$ & 9.3 & 4.45 \\
\hline K-U & 31.95 & 1.87 & 2.13 & 9.33 & 0.15 & 35.27 & 8.08 & 0.17 & 0.5 & 0.41 & 0.12 & 9.01 & 98.99 & 0.03 & 4.9 & 4.12 \\
\hline K17/04 & 28.52 & 1.09 & 1.74 & 7.97 & 0.13 & 32.72 & 12.29 & 0.31 & 0.99 & 0.4 & 0.55 & 12.31 & 99.02 & 0.05 & 8.5 & 3.81 \\
\hline K28/05 & 27.79 & 1.67 & 2.08 & 8.57 & 0.16 & 31.37 & 13.33 & 0.37 & 1.29 & 0.56 & 0.40 & 10.91 & 98.50 & 0.19 & 7.3 & 3.64 \\
\hline K25/04 & 28.96 & 1.44 & 1.89 & 8.83 & 0.16 & 33.31 & 11.51 & 0.22 & 1.23 & 0.55 & 0.39 & 10.03 & 98.52 & 0.05 & 7.8 & 2.28 \\
\hline K20-05 & 27.01 & 0.98 & 1.3 & 7.99 & 0.14 & 33.94 & 13.98 & 0.25 & 0.5 & 0.47 & 0.49 & 11.92 & 98.97 & 0.08 & 10.5 & 1.40 \\
\hline K24/04A & 25.88 & 1.75 & 2.27 & 9.86 & 0.2 & 31.54 & 13.96 & 1.08 & 0.86 & 0.82 & 0.08 & 10.41 & 98.70 & 0.06 & 9.9 & 0.56 \\
\hline K2-03 & 29.95 & 1.33 & 2.03 & 8.53 & 0.15 & 32.66 & 9.54 & 3.94 & 1.61 & 0.45 & 1.34 & 6.74 & 98.27 & 0.28 & 6.3 & 0.42 \\
\hline K24/04B & 27.84 & 1.4 & 1.84 & 9.45 & 0.18 & 33.86 & 10.86 & 2.26 & 0.95 & 0.63 & 0.34 & 9.61 & 99.22 & 0.14 & 9.2 & 0.39 \\
\hline UV-K1-15 & 27.28 & 0.87 & 1.52 & 7.53 & 0.13 & 30.95 & 9.74 & 6.07 & 1.75 & 0.35 & $\mathrm{n} / \mathrm{a}$ & 7.95 & 94.14 & 0.24 & 7.7 & 0.23 \\
\hline UV-K1-05 & 27.26 & 1.03 & 1.8 & 7.07 & 0.12 & 29.92 & 9.44 & 6.23 & 1.88 & 0.34 & 5.68 & 7.84 & 98.60 & 0.31 & 7.7 & 0.17 \\
\hline
\end{tabular}

Major elements, $\mathrm{Cl}, \mathrm{S}$, $\mathrm{LOI}$ (loss on ignition), $\mathrm{CO}_{2}$ and $\mathrm{H}_{2} \mathrm{O}$ are in wt \%.

Depth of sampling (in meters) reflect most possible position in the mining pit for most samples taken from stockpiles.

$\mathrm{CK}=$ coherent kimberlite; $\mathrm{VK}=$ volcaniclastic kimberlite; $\mathrm{AC}=$ Autolithic clasts of kimberlite (or autoliths) - hosted in VK; $\mathrm{n} / \mathrm{a}=$ not available.

Source: Kamenetsky et al. (2012). 
TABLE 3: Summary of mineral phases hosted in multiphase melt inclusions in olivine and groundmass monticellite, spinel, perovskite and calcite from serpentinised and unserpentinised Udachnaya-East kimberlite. The abundance (\%) represents the average proportion of each phase hosted within each mineral.

\begin{tabular}{|c|c|c|}
\hline Mineral & Ideal Formulae & Abundance (\%) \\
\hline \multicolumn{3}{|l|}{ Olivine } \\
\hline Halite/Sylvite & $\mathrm{NaCl} / \mathrm{KCl}$ & 33 \\
\hline \multirow[t]{3}{*}{ Alkali carbonates } & Ca-Mg-Na-K-Ba-Sr $\pm \mathrm{S}$ & \multirow{3}{*}{28} \\
\hline & \multirow[b]{2}{*}{ Shortite: $\mathrm{Na}_{2} \mathrm{Ca}_{2}\left(\mathrm{CO}_{3}\right)_{3}$} & \\
\hline & & \\
\hline Spinel & Fe-Ti-Mg-Cr-Al & 8 \\
\hline Alkali-sulphates & $\mathrm{Na}-\mathrm{K}$ : Arcanite $\left(\mathrm{K}_{2} \mathrm{SO}_{4}\right)$ & 7 \\
\hline Tetraferriphlogopite & $\mathrm{KMg}_{3} \mathrm{Fe}^{3+} \mathrm{Si}_{3} \mathrm{O}_{10}(\mathrm{OH})_{2}$ & 5 \\
\hline Sulphides & \multirow{2}{*}{$\begin{array}{c}\text { Fe-Ni: Djerfisherite } \\
\left(\mathrm{K}_{6} \mathrm{Na}\left(\mathrm{Fe}^{2+}, \mathrm{Cu}, \mathrm{Ni}\right)_{25} \mathrm{~S}_{26} \mathrm{Cl}\right)\end{array}$} & \multirow{2}{*}{5} \\
\hline & & \\
\hline Phlogopite & $\mathrm{KMg}_{3}\left(\mathrm{AlSi}_{3} \mathrm{O}_{10}\right)(\mathrm{F}, \mathrm{OH})_{2}$ & 4 \\
\hline Monticellite & $\mathrm{CaMgSiO}_{4}$ & 3 \\
\hline Perovskite & $\mathrm{CaTiO}_{3}$ & 3 \\
\hline Humite & $(\mathrm{Mg}, \mathrm{Fe})_{7}\left(\mathrm{SiO}_{4}\right)_{3}(\mathrm{~F}, \mathrm{OH})_{2}$ & 2 \\
\hline Apatite & $\mathrm{Ca}_{5}\left(\mathrm{PO}_{4}\right)_{3}(\mathrm{~F}, \mathrm{Cl}, \mathrm{OH})$ & 2 \\
\hline \multicolumn{3}{|c|}{ Monticellite, Spinel, Perovskite } \\
\hline Sylvite/Halite & $\mathrm{KCl} / \mathrm{NaCl}$ & 40 \\
\hline Alkali carbonates & Ca-Mg-Na-K & 30 \\
\hline Fe-Mg-Ti-spinel & Fe-Mg-Ti & 10 \\
\hline Alkali-sulphates & $\mathrm{Na}-\mathrm{K}$ & 10 \\
\hline Phlogopite & $\mathrm{KMg}_{3}\left(\mathrm{AISi}_{3} \mathrm{O}_{10}\right)(\mathrm{F}, \mathrm{OH})_{2}$ & 5 \\
\hline Perovskite & $\mathrm{CaTiO}_{3}$ & 5 \\
\hline \multicolumn{3}{|c|}{ Calcite } \\
\hline Halite/Sylvite & $\mathrm{NaCl} / \mathrm{KCl}$ & 55 \\
\hline Alkali-carbonates & Ca-Mg-Na-K $\pm S$ & 40 \\
\hline Djerfisherite & $\mathrm{K}_{6} \mathrm{Na}\left(\mathrm{Fe}^{2+}, \mathrm{Cu}, \mathrm{Ni}\right)_{25} \mathrm{~S}_{26} \mathrm{Cl}$ & 5 \\
\hline
\end{tabular}

